University of Michigan Law School

University of Michigan Law School Scholarship Repository

Articles

Faculty Scholarship

2002

\title{
The Writings of John Barker Waite and Thomas Davies on the Search and Seizure Exclusionary Rule
}

Yale Kamisar

University of Michigan Law School, ykamisar@umich.edu

Available at: https://repository.law.umich.edu/articles/268

Follow this and additional works at: https://repository.law.umich.edu/articles

Part of the Criminal Procedure Commons, Fourth Amendment Commons, Legal Writing and Research Commons, and the Supreme Court of the United States Commons

\section{Recommended Citation}

Kamisar, Yale. "The Writings of John Barker Waite and Thomas Davies on the Search and Seizure Exclusionary Rule." Mich. L. Rev. 100, no. 7 (2002): 1821-66.

This Essay is brought to you for free and open access by the Faculty Scholarship at University of Michigan Law School Scholarship Repository. It has been accepted for inclusion in Articles by an authorized administrator of University of Michigan Law School Scholarship Repository. For more information, please contact mlaw.repository@umich.edu. 


\title{
THE WRITINGS OF JOHN BARKER WAITE AND THOMAS DAVIES ON THE SEARCH AND SEIZURE EXCLUSIONARY RULE
}

\author{
Yale Kamisar*
}

\section{INTRODUCTION}

After browsing through many volumes of the Michigan Law Review, searching for the article I would discuss on the occasion of the law review's 100 th anniversary, I wound up with two "finalists": a 1955 article by Professor John Barker Waite on the law of arrest search and seizure (on further reflection, four Michigan Law Review commentaries on the general subject written by Waite between 1933 and 1955$)^{1}$ and a monumental 200-page article (surely one of the longest articles ever to appear in the Michigan Law Review) by Thomas Davies on the "original Fourth Amendment."

Convincing myself that their writings could be made to fit together, I resolved the matter by choosing the works of both commentators. One important consideration was my belief that each had something important to say about the search and seizure exclusionary rule, a controversy that, despite eighty years of intense debate, shows no signs of letting up. ${ }^{3}$ Waite and Davies are a study in contrasts. Waite

* Clarence Darrow Distinguished University Professor, University of Michigan Law School; Visiting Professor, University of San Diego Law School. A.B. 1950, N.Y.U.; LL.B. 1954, Columbia; LL.D. 1978 John Jay College of Criminal Justice, City University of New York; LL.D. 1979, Puget Sound.

1. John Barker Waite, Comment, Evidence - Police Regulation by Rules of Evidence, 42 MICH. L. REV. 679 (1944) [hereinafter Waite (1944)]; John Barker Waite, Judges and the Crime Burden, 54 MICH. L. REV. 169 (1955) [hereinafter Waite (1955)]; John Barker Waite, Public Policy and the Arrest of Felons, 31 MICH. L. REV. 749 (1933) [hereinafter Waite (1933)]; J.B.W., Comment, Searches and Seizures - The Criterion of Reasonableness, 42 MICH. L. REV. 147 (1943) [hereinafter Waite (1943)].

2. Thomas Y. Davies, Recovering the Original Fourth Amendment, $98 \mathrm{MICH}$. L. REV. 547 (1999).

3. See, e.g., Akhil Reed Amar, Fourth Amendment First Principles, 107 HARV. L. REv. 757 (1994) [hereinafter Amar, First Principles]; Tracey Maclin, When the Cure for the Fourth Amendment is Worse than the Disease, 68 S. CAL. L. REV. 1 (1994); Christopher Slobogin, Why Liberals Should Chuck the Exclusionary Rule, 1999 U. ILL. L. REV. 363; Carol S. Steiker, Second Thoughts About First Principles, 107 HARV. L. REV. 820 (1994); William J. Stuntz, The Virtues and Vices of the Exclusionary Rules, 20 HARV. J.L. \& PUB. POL'Y 443 (1997) [hereinafter Stuntz, Virtues and Vices].

Judge (later Justice) Benjamin Cardozo once opined that "[t]o what [has been] written [about the exclusionary rule], little of value can be added." People v. Defore, 150 N.E. 585 , 587 (N.Y. 1926). He made this comment three-quarters of a century ago! But it does not 
was sympathetic to the needs and interests of the police and he resented the attempts of the courts "to control police conduct by the indirection of rules of evidence judicially made for that purpose." If anything, Davies believes the courts are too timid in placing restrictions on the police.

Waite was a colorful, crusty law professor who wrote with power and passion. Sometimes, as he noted, he drew upon his own frequent contacts with the police and his observations of their methods. ${ }^{5}$ Although the author of a major empirical study, ${ }^{6}$ Davies, as his Michigan article well demonstrates, is a prodigious "library researcher." His arguments are spelled out painstakingly and his writing is heavily footnoted. ${ }^{7}$

Professor Waite was a member of the University of Michigan law faculty from 1912-51. ${ }^{8}$ Although the grandson of the seventh Chief Justice of the United States, Morrison R. Waite, he did not treat

seem to have had a chilling effect on many law professors. (Of course, in the Defore case Judge Cardozo proceeded to write some of the most famous lines ever written on the subject.)

4. Waite (1944), supra note 1, at 691.

5. Waite (1933), supra note 1, at 766 n.36. In another article, Professor Waite disclosed that "[d]uring the later years of prohibition [he] participated as spectator in numerous police raids on blind pigs." Waite (1944), supra note 1, at 685.

6. Thomas Y. Davies, A Hard Look at What We Know (and Still Need to Learn) About the "Costs" of the Exclusionary Rule, 1983 AM. B. FOUND. RES. J. 611 [hereinafter Davies, A Hard Look].

7. Davies' Michigan Law Review article contains 574 footnotes, some fifty of which are at least half a page long. Davies, supra note 2. It should be pointed out that as big as Davies' article is, it is dwarfed by William J. Cuddihy's 1,696 page unpublished 1990 doctoral dissertation on the origins and original meaning of the Fourth Amendment. See William J. Cuddihy, The Fourth Amendment: Origins and Original Meaning (1990) (unpublished Ph.D. dissertation, Claremont Graduate School). Dissenting in Vernonia School District $47 J v$. Acton, 515 U.S. 646, 669 (1995), Justice O'Connor called Cuddihy's dissertation "one of the most exhaustive analyses of the original meaning of the Fourth Amendment." (It is hard to see how anyone could dispute that.) The dissertation is the subject of a thoughtful essay review. Morgan Cloud, Searching through History; Searching for History, 63 U. CHI. L. REV. 1707 (1996). Davies refers to Cuddihy's dissertation a number of times, but does not always agree with him. Cuddihy only examines search and seizure up to 1791 . On the other hand, much of Davies' article discusses how and why nineteenth century developments undermined the assumptions and expectations regarding the drafting and adoption of the Fourth Amendment. See, e.g., Davies, supra note 2, at 655 n.299. Consider Larry Kramer, Fidelity to History - and Through It, 65 FORDHAM L. REV. 1627, 1641 (1997), who wrote: "[W]e cannot know [whether the original understanding still makes sense] until we have examined what happened after. Subsequent history is essential to determine what our Constitution has become and to decide what it should continue becoming."

8. One of Professor Waite's many students was John D. Voelker, who wrote the bestselling murder mystery, Anatomy of a Murder, under his pen name, Robert Traver. ROBERT TrAVER, ANATOMY OF A MURDER (1958). At one point in Voelker's book, the defense lawyer recalls what "my old Crimes professor, J. B. "Jabby' White," had told him about the law of homicide. $I d$. at 37. This is an obvious reference to Professor Waite - he sometimes signed his work J. B. Waite and he was sometimes called "Jabby" Waite. Moreover, when a gathering of alumni honored him a dozen years after his retirement, Waite told the group that Voelker had made him famous by referring to him in the book. 
judges (or Supreme Court justices) kindly. He blamed them for "deliberately restrict[ing] police efficiency in the discovery of criminals." By protecting "discovered criminal[s]" from "deserved punishment," charged Waite, "judges are derogating from the force of deterrence and contributing to the country's already too heavy and increasing burden of crime." 10

As might be expected from what has already been said, Professor Waite was an implacable and outspoken opponent of the exclusionary rule. Then, as now, he has had a lot of company. ${ }^{11}$ Among those who have shared Waite's view are Chief Justice Burger and Chief Justice Rehnquist. Each has made arguments against the rule reminiscent of those made by Professor Waite decades earlier. ${ }^{12}$

Waite was quite familiar with the claims made by proponents of the exclusionary rule: if illegally obtained evidence is excluded, police overzealousness "will diminish and cease"; if illegally obtained evidence is admitted, police misconduct "will flourish and increase." 13 But he was highly skeptical: "It is a logical enough theory, impregnable in the library." 14 (I consider this one of the most memorable statements ever made in the long debate over the exclusionary rule. $)^{15}$

Thomas Davies has been a member of the University of Tennessee law faculty since 1986. While he was an American Bar Foundation project director, and prior to entering teaching, he published what is widely regarded as the most careful and most balanced evaluation of the exclusionary rule's effects on criminal law enforcement. ${ }^{16}$ (A

9. Waite (1955), supra note 1 , at 169.

10. Id. at 186 (emphasis omitted).

11. In an appendix to his dissenting opinion in Bivens v. Six Unknown Named Agents, 403 U.S. 388, 426-27 (1971), Chief Justice Burger lists fourteen books and articles expressing "disenchantment with the exclusionary rule." Waite's 1944 and 1955 articles are among those listed.

12. See Stone v. Powell, 428 U.S. 465, 498 (1976) (Burger, C.J., concurring); Bivens, 403 U.S. at 415 (Burger, C.J., dissenting); see also California v. Minjares, 443 U.S. 916 (1979) (Rehnquist, J., dissenting from denial of stay).

13. Waite (1944), supra note 1 , at 685.

14. Id. Of course, one can certainly say the same thing about "the theory" put forward by opponents of the exclusionary rule: there are many ways to enforce the exclusionary rule other than by excluding the evidence obtained in violation of it; the offending officer "might have been resisted, or sued for damages, or even prosecuted for oppression." People v. Defore, 150 N.E. 585, 586-87 (N.Y. 1926).

15. More generally, Waite complained about judicial rulings (or, as he put it, "judicial legislation") "based upon incomplete information" and "formulated without realization of its probable effects." Waite (1944), supra note 1 , at 679,685 . He would find some kindred spirits today. See, e.g., Tracey L. Meares \& Bernard E. Harcourt, Transparent Adjudication and Social Science Research in Constitutional Criminal Procedure, 90 J. CRIM. L. \& CRIMINOLOGY 733 (2000).

16. See Wayne R. LaFave, Search and Seizure: A Treatise on the Fourth AMENDMENT $\$ 1.3$ (c), at 58 (3d ed. 1996), so describing Davies, A Hard Look, supra note 6. 
decade earlier, as a law student, Davies had published a much-cited "critique" of empirical evaluations of the exclusionary rule.) ${ }^{17}$

It should be made plain that Davies' Michigan Law Review article does not focus on the search and seizure exclusionary rule. ${ }^{18}$ Nevertheless, his "recovering [of the Fourth Amendment's] original understanding from the historical sources"19 and his discussion of how dramatic changes in legal and social institutions turned out to undercut the Framers' premises, make his article indispensable reading (and re-reading) for anyone interested in the exclusionary rule debate. While Davies' interest in search and seizure has never wavered, one might say that, in turning to legal history, he has shifted methodology as the course of the search and seizure debate has shifted grounds. Although Davies has a Ph.D. in political science, he has no formal training in history. His political science training and his litigation experience, however, have given him a strong background in digging out data and making sense of it. His 200-page Michigan Law Review article is the result. ${ }^{20}$

\section{PROFESSOR WAITE'S ATTACK ON THE EXCLUSIONARY RULE}

A. Judges of the federal courts and those in eighteen of the states have evolved a policy of rebuking police who transgress [search and seizure] limitations by reversing the convictions of criminals discovered through the transgression. Any evidence of guilt so obtained must, these courts insist, be suppressed and kept from the knowledge of trial juries....

This odd procedure of exempting known criminals from punishment as a means of keeping the police in order has been

17. See Critique, On the Limitations of Empirical Evaluations of the Exclusionary Rule: A Critique of the Spiotto Research and United States v. Calandra, 69 Nw. U. L. REV. 740 (1974).

18. The most noteworthy feature of Davies' article is probably his attack on the "nearuniversal assumption that the first clause of the Fourth Amendment was meant to articulate a broad reasonableness-in-the-circumstances standard." Davies, supra note 2, at 591. Davies maintains that "the Framers understood 'unreasonable searches and seizures' simply as a pejorative label for the inherent illegality of any searches or seizures that might be made under general warrants," id. at 551; " 'unreasonable' was derived from Sir Edward Coke's earlier use of 'against reason' as a synonym for inherent illegality or unconstitutionality." Id. at 555 .

One does not have to agree with Davies on this point to find persuasive his explanation of why the Framers did not mention or even think about a search and seizure exclusionary rule, but why, considering the legal and social changes that have occurred with the passage of time, there now is (and has long been) a compelling need for such a rule.

19. Id. at 552 .

20. We can expect more ventures into legal history by Davies in the years ahead. His newest article, almost as long as his Michigan article, is The Fictional Character of Law-andOrder Originalism: A Case Study of the Distortions and Evasions of Historical Arrest Doctrine in Atwater v. Lago Vista, 37 WAKE FOREST L. REV. 239 (2002). 


\section{discussed, applauded, or condemned by many commentators. ${ }^{21}$}

Is the exclusionary rule procedure odd, clumsy or awkward? I think not. When the defendant seeks to prevent the government from using the fruits of police illegality, the protagonists are in place. This is the occasion when the defendant has the maximum incentive to challenge the police conduct and, if he is indigent - as some eighty percent of criminal defendants are ${ }^{22}$ - the services of court-appointed counsel. Why make the alleged victim of police illegality start a new proceeding in another court? Why require the criminal defendant to look for a lawyer willing to bring a civil lawsuit, often without any fee, against "a team of professional investigators and testifiers" ? ${ }^{23}$ Why make the criminal defendant look for a lawyer willing to run the risk of antagonizing the police? $?^{24}$

As Professor Stuntz has observed:

One of the [exclusionary] rule's great virtues is its efficiency. Claims are inexpensive to raise, and the facts on which they rest usually do not involve much independent digging by defense counsel. ${ }^{25}$

[The fact that the exclusionary rule is tied to criminal prosecutions] ensures that lots of claims are raised, which in turn allows courts to serve as reasonably good watchdogs for certain kinds of police misbehavior. Using criminal litigation to regulate the police thus has enormous administrative and remedial advantages. The point goes well beyond search and seizure law - police interrogation is much more easily monitored through Miranda claims than through damages actions. Indeed, it goes well beyond the police. It is much easier to regulate misbehavior in jury selection by reversing convictions than by encouraging lawsuits by potential jurors; that is why our law uses criminal litigation to protect not only defendants but jurors as well. ${ }^{26}$

It is worth remembering that American criminal procedure "imposes procedural, regulations on the criminal process by

21. Waite (1955), supra note 1 , at $169-70$ (citation omitted). Compare Chief Justice Burger's view of the exclusionary rule: "A more clumsy, less direct means of imposing sanctions is difficult to imagine." Stone v. Powell, 428 U.S. 465, 498 (1976) (concurring opinion). Consider, too, Akhil Reed Amar's statement that the Supreme Court "has concocted the awkward and embarrassing remedy of excluding reliable evidence of criminal guilt." Amar, First Principles, supra note 3, at 785.

22. Stuntz, Virtues and Vices, supra note 3 , at 452.

23. Anthony G. Amsterdam, Perspectives on the Fourth Amendment, 58 MINN. L. REV. 349,430 (1974).

24. See id.

25. Stuntz, Virtues and Vices, supra note 3, at 453.

26. Id. at 455. Stuntz adds, however, that while suppression motions "may be costeffective, they are not costless." Id. at 453 . In a world where many defense lawyers have severely limited resources, the many suppression motions that are made "presumably displace something else. The most obvious 'something else' is factual argument, argument about the merits of the criminal charge." Id. at 453. 
constitutional command." 27 Why should Fourth Amendment litigation be exempted from that process?

"The survival of our system of criminal justice and the values which it advances," observed a distinguished Attorney General's Committee forty years ago, "depends upon a constant, searching, and creative questioning of official decisions and assertions of authority at all stages of the process." ${ }^{28}$ In context, it is clear that the Committee meant the criminal process. Because the danger is plain that a criminal will destroy or hide evidence of his crime if given advance notice, we must postpone an opportunity for a hearing on the issue. But why does it follow that no meaningful challenge of the police action should be permitted at any stage of the criminal process - not even long after the suspect is in custody and the evidence is in the police station? This would be the result if the exclusionary rule were to be abolished.

B. [J]udges have themselves imposed [a number of] narrowly restrictive limitations on police activity. Then, having created these limitations, they themselves undertake to assure police obedience to them. To this end they ignore the possibility of direct action against individual officers and proceed by indirection. ${ }^{29}$

$$
* * *
$$

To assume the ineffectiveness of direct action by suit against an overzealous officer merely from the absence of such suits in appellate court reports is unjustifiable; the relation of appeals to suits begun depends too largely upon the nature of the action; these may be so simple and successful as to provoke no appeal. That no guilty guncarrier has ever brought suit for damages may be conceded; he would find small sympathy before a jury.... As for unlawful arrest of innocent persons, the writer has seen overzealous policemen sweating copiously in fear of results and has known judgments rendered against them. If suits are not begun, it is far more likely that no real damage was suffered than that suit would be unsuccessful. ${ }^{30}$

27. U.S. ATT'Y Gen.'S COMM. ON POVERTy \& THE AdMIN. OF FEd. CRIM. JuST., REPORT 11 (1963) (emphasis added). The Report is often called The Allen Report, after the Chairman of the Committee, Professor Francis A. Allen. At the time Allen was a member of the University of Chicago law faculty, but a short time later he became dean of the University of Michigan Law School.

28. Id.

29. Waite (1955), supra note 1 , at 169.

30. Waite (1944), supra note 1, at 692. "Moreover," added Waite, "it should not be forgotten that civil action by the individual injured is not the only alternative for enforcing observance of official obligations and limitations.... [C]ertainly [recalcitrant law enforcement officers] could be subjected, as a practical manner, to proceedings instituted by court prosecutors or district attorneys." Id. But it is now fairly clear, as a practicable matter, that criminal prosecutions are not a viable alternative to the exclusionary rule. As Justice 
As Justice Frankfurter pointed out on one of the last occasions he wrote about the pre-Miranda due process/"totality of the circumstances"/"voluntariness" test for admitting confessions:

[I]n many of the cases in which the command of the Due Process Clause has compelled us to reverse state convictions obtained by impermissible methods, independent corroborating evidence left little doubt of the truth of what the defendant had confessed. Despite such verification ... we were constrained to find that the procedures leading to [the defendant's] conviction had failed to afford him that due process of law which the Fourteenth Amendment guarantees. ${ }^{31}$

Why can't the criminal justice system make use of an involuntary confession that is so impressively corroborated that there is no doubt about its trustworthiness? The exclusion of a reliable confession, no less than the exclusion of illegally seized evidence, directly serves only to protect those from whom incriminating evidence has been obtained. (Most victims of impermissible interrogation practices never do confess or do not make a confession that "checks out.") Why, during the three decades that the due-process voluntariness test reigned supreme, did the courts, to use Professor Waite's words, "ignore the possibility of direct actions against individual [police interrogators] and [instead] proceed by indirection"? ?2

In theory at least - the same theory that opponents of the search and seizure exclusionary rule are quick to invoke - permitting the use of verifiable coerced confessions would not leave the guarantee against oppressive or otherwise objectionable police interrogation methods without alternative means of protection.

Potter Stewart once pointed out, "criminal sanctions are too great a penalty and too strong a deterrent to effective law enforcement" to be applied whenever an officer negligently violates the Fourth Amendment and, because "juries are inclined to credit the testimony" of lawless police officers, "it is difficult to obtain a conviction for willful deprivation of fourth amendment rights." Potter Stewart, The Road to Mapp v. Ohio and Beyond: The Origins, Development and Future of the Exclusionary Rule in Search-and-Seizure Cases, 83 COLUM. L. REV. 1365, 1386-87 (1983).

31. Rogers v. Richmond, 365 U.S. 534, 541 (1961). For other emphatic statements of what has been called the "police methods" test for the admissibility of confessions, see Lego v. Twomey, 404 U.S. 477, 485 (1972) and Jackson v. Denno, 378 U.S. 368, 376-77 (1964). As some commentators pointed out as early as Ashcraft v. Tennessee, 322 U.S. 143 (1944), the Court seemed to be applying a test for the admissibility of confessions that reflected less a concern with the reliability of a particular confession than disapproval of police interrogation methods considered offensive or subject to serious abuse. See Francis A. Allen, The Supreme Court, Federalism, and State Systems of Criminal Justice, 8 DEPAUL L. REV. 213, 233-37 (1959); Monrad G. Paulsen, The Fourteenth Amendment and the Third Degree, 6 STAN. L. REV. 411, 429 (1954).

32. Waite (1955), supra note 1 , at 169 . It will not do to point to the privilege against compelled self-incrimination. The pre-Miranda due process "voluntariness" doctrine was not based on the self-incrimination clause and the courts that applied and developed the test did so without regard to the privilege. It was not until 1964 , that the privilege was deemed applicable to the states, Malloy v. Hogan, 378 U.S. 1 (1964), and it was not until two years later, when the Court handed down Miranda v. Arizona, 384 U.S. 436 (1966), that the privilege was held to apply to custodial interrogation. 
During the pre-Miranda era, various state laws made it a crime for a police officer to deny a lawyer the opportunity to meet with a client who had been arrested or to fail to notify a suspect's relatives that he had been arrested..$^{33}$ Other state laws penalized police officers who sought to elicit confessions by violence or threats of violence. ${ }^{34}$ Furthermore, false imprisonment and assault are torts. Why were these various "alternative remedies" insufficient?

Of course, the Court rejected or, so far as I am aware, never seriously considered these "alternative approaches" to the coerced confession problem. Indeed, so far as I am aware, no government lawyer ever made the "alternative remedies" argument in this context. If a confession had been obtained by police methods that rendered it "involuntary" or "coerced" - and thus violated due process - it had to be excluded, however verifiable. It was that simple. But why is it not that simple when physical evidence is obtained in violation of due process, when the police have violated a constitutional protection that is "basic to a free society?" 35

As most critics of the exclusionary rule have done in the past seventy-five years, Professor Waite quotes from Benjamin Cardozo's famous opinion in People v. Defore, ${ }^{36}$ the New York case that rejected the exclusionary rule (when the states still had an option), which argued that there was no shortage of alternatives to the exclusionary rule: "The officer might have been resisted, or sued for damages, or even prosecuted for oppression." ${ }^{37}$ If these tort remedies and other alternatives to the exclusionary rule have been ineffective, one reason

33. For a sampling of such statutes, see Justice Frankfurter's plurality opinion in Culombe v. Connecticut, 367 U.S. 568, 586-87 n.29 (1961).

34. See id. at 586 n.28.

35. Although it upheld Dr. Wolf's conviction in Wolf v. Colorado, 338 U.S. 25 (1949), "the Court had apparently treated the police behavior [that turned up the evidence] in Wolf as violating the defendant's Fourteenth Amendment rights; that is to say, 'rights basic to a free society' or 'implicit in the concept of ordered liberty' had been invaded." Francis A. Allen, Federalism and the Fourth Amendment: A Requiem for Wolf, 1961 SUP. CT. REV. 1, 9. Although the type of illegal search that occurred in Wolf is never discussed, it appears to have been a "routine" rather than an "aggravated" one. See Yale Kamisar, Wolf and Lustig Ten Years Later: Illegal State Evidence in State and Federal Courts, 43 MINN. L. REv. 1083, 1101-02 (1959); see also Donald A. Dripps, At the Borders of the Fourth Amendment: Why a Real Due Process Test Should Replace the Outrageous Government Conduct Defense, 1993 U. ILL. L. REV. 261, 267 n.43 (best reading of Wolf is that it incorporated the Fourth Amendment but not the exclusionary rule). Mapp v. Ohio, 397 U.S. 643 (1961), overruling Wolf, held that the Fourteenth Amendment incorporated the Fourth Amendment along with the exclusionary rule.

36. 150 N.E. 585 (N.Y. 1926), quoted in Waite (1944), supra note 1, at 682, 683-84.

37. Defore, 150 N.E. at 587. 
is that, to use Professor Waite's words, "no real damage was suffered." ${ }^{38}$ But there are other explanations as well.

Although Justice Potter Stewart was on the Supreme Court when Mapp v. Ohio ${ }^{39}$ was decided, he did not address the question of whether the federal exclusionary rule should be imposed on state courts because he did not believe the question was properly before the Court. ${ }^{40}$ A quarter-century later, however (shortly after he had retired from the Court), Justice Stewart left no doubt that he agreed with the Mapp majority's conclusion. Why? Because in the real world none of the theoretical alternatives to the exclusionary rule amounted to much:

In sum, the most "powerful" remedies, criminal prosecutions for willful violation of the fourth amendment and actions for injunctions against large-scale violations, are rarely brought and rarely succeed. [As for damage actions, they are] expensive, time-consuming, not readily available and rarely successful. As a result, the deterrent effect of these actions can hardly be said to be great, since the prospect of a judgment for money damages is extremely remote.

Taken together, the currently available alternatives to the exclusionary rule satisfactorily achieve some, but not all, of the necessary functions of a remedial measure. They punish and perhaps deter the grossest of violations, as well as governmental policies that legitimate these violations. They compensate some of the victims of the most egregious violations. But they do little, if anything, to reduce the likelihood of the vast majority of fourth amendment violations - the frequent infringements motivated by commendable zeal, not condemnable malice. For these violations, a remedy is required that inspires the police officer to channel his enthusiasm to apprehend a criminal toward the need to comply with the dictates of the fourth amendment. There is only one such remedy - the exclusion of illegally obtained evidence. ${ }^{41}$

We now know that these alternative remedies were woefully ineffective. We now know that, Professor Waite's claim to the contrary notwithstanding, very few, if any, overzealous police officers at 449 :

38. Waite (1944), supra note 1, at 692. Consider Stuntz, Virtues and Vices, supra note 3,

[T] here is a kind of damages case one does not see: the lawsuit challenging the search of a suspect's automobile or briefcase or jacket pocket. Such suits are almost never filed, both because the targets of the searches may be unattractive to juries ... and because neither judges nor juries would award any significant sum of money to compensate for the fairly trivial harm of having the trunk of one's car opened. Save for house searches, and not often even there, Fourth Amendment damages claims tend not to involve searches at all. They involve seizure of suspects, and they tend to challenge the violent way in which these seizures were carried out. That means a damages system would probably focus, as current Fourth Amendment damages litigation does focus, on police violence and illegal detention.

39. 367 U.S. 643 (1961) (imposing the search and seizure exclusionary rule on the states as a matter of fourteenth amendment due process).

40. Stewart, supra note 30 , at 1368,1389 .

41. Id. at $1388-89$ (emphasis added). 
sweat copiously over the prospect of being sued or prosecuted. How do we know this? From the reaction of law enforcement officials, thirty-five years after the Defore case, when the U.S. Supreme Court imposed the search and seizure exclusionary rule on all states.

In fact, New York City Police Commissioner Michael Murphy likened the Mapp case to a "tidal wave" and an "earthquake." 42 As the commissioner recalled some years later:

I can think of no decision in recent times in the field of law enforcement which had such a dramatic and traumatic effect as $[$ Mapp] .... As the then commissioner of the largest police force in this country I was immediately caught up in the entire problem of reevaluating our procedures, which had followed the Defore rule, and... creating new polices and new instructions for the implementation of Mapp.... [Decisions such as Mapp] create tidal waves and earthquakes which require rebuilding of our institutions sometimes from their very foundations upward. Retraining sessions had to be held from the very top administrators down to each of the thousands of foot patrolmen and detectives engaged in the daily basic enforcement function. ${ }^{43}$

Why did Mapp have "such a dramatic and traumatic effect"? Why did it necessitate "retraining" from top to bottom? What was the old search and seizure training like? Was there any? How does one "implement" Mapp, a case that simply imposed a remedy for a violation of a body of law the police were supposed to be obeying all along?

What did the commissioner mean when he tried to defend his department's disinterest in the law of search and seizure prior to Mapp by noting that his department "had followed the Defore rule"? To be sure, Defore permitted New York prosecutors to use illegally seized evidence, but it did not - as the commissioner evidently believed allow the police to commit illegal searches. What better evidence is there of the ineffectiveness of the existing alternatives to the exclusionary rule than the police reaction to Mapp?

As Donald Dripps has observed, "[i]f effective civil remedies carried the political appeal that would commend them to legislators, those remedies would have forced the police to comply with the

42. See the quotation from Commissioner Michael Murphy set forth immediately below.

43. Michael Murphy, Judicial Review of Police Methods in Law Enforcement: The Problem of Compliance by Police Departments, 44 TEXAS L. REV. 939, 941 (1966).

Those who believed or assumed that various alternatives to the search and seizure exclusionary rule were adequate may have suffered an even greater blow when, unaware that there was a reporter in the audience, New York City Deputy Police Commissioner Leonard Reisman explained to a large group of detectives at a post-Mapp training session why they had to learn the law of search and seizure at this late date in their careers: "[In the past] nobody bothered to take out search warrants .... [T] he Supreme Court had ruled that evidence obtained without a warrant - illegally if you will - was admissible in state courts. So the feeling was, why bother?" Sidney E. Zion, Detectives Get a Course in Law, N.Y. TIMES, Apr. 28, 1965, at 50. 
Amendment in the [years before] Mapp [and] Mapp would have discomfited the police but little." ${ }^{44}$

It appears that, prior to Mapp, the police were not the only New York law enforcement officials unfamiliar with and unconcerned about the law of search and seizure. Professor Richard Uviller, a New York prosecuting attorney when Mapp was handed down, recalled that he quickly "cranked out a crude summary" of federal search and seizure law just before the next state convention of district attorneys took place and that he "had an instant runaway best seller. It was as though we had made a belated discovery that the fourth amendment applied in the State of New York." ${ }^{45}$ Uviller's last comment, I believe, sums up the situation in New York before and after Mapp quite well.

The response of New York law enforcement officials to the imposition of the search and seizure exclusionary rule was hardly unique. When, six years earlier, in People v. Cahan ${ }^{46}$ the California Supreme Court adopted the exclusionary rule on its own initiative, the reaction of the Los Angeles Chief of Police, William Parker, was quite similar to the reaction his New York City counterpart would have when Mapp came down. Chief Parker issued both a warning and a promise:

[O]ur ability to prevent the commission of crimes has been greatly diminished. The actual commission of a serious criminal offense will not justify affirmative police action until such time as the police have armed themselves with sufficient information to constitute "probable cause" for an actual arrest. ${ }^{47}$

$$
* * *
$$

We will meticulously abide by ... the Cahan case and subsequent cases dealing with the exclusionary rule. The criminal will continue to benefit and the law-abiding public will continue to pay the bill. ${ }^{48}$

$* * *$

As long as the Exclusionary Rule is the law of California, your police will respect it and operate to the best of their ability within the framework of limitations imposed by that rule. We feel obligated to present the case

44 Donald Dripps, Akhil Amar on Criminal Procedure and Constitutional Law: "Here I Go Down that Wrong Road Again," 74 N.C.L. REV. 1559, 1606 (1996).

45. H. Richard Uviller, The Acquisition of Evidence for Criminal Prosecution: Some Constitutional Premises and Practices in Transition, 35 VAND. L. REV. 501,502 (1982).

46. 282 P.2d 905 (1955).

47. William H. Parker, Parker on POlice 117 (O.W. Wilson ed., 1957) (excerpts from a statement filed with the California Judiciary Subcommittee on Illegal Searches, Seizures, and the Laws of Arrest, Jan. 1956). 1956).

48. Id. at 125 (excerpts from an address delivered at the Ebell Club, Los Angeles, Mar., 
against this rule of evidence... to speak of how it affects our ability to protect you against the criminal army. ${ }^{49}$

Why, prior to Cahan, did Chief Parker permit his officers to take "affirmative action" without bothering to arm themselves with sufficient information to constitute "probable cause"? Why, prior to Cahan, were Los Angeles police not "meticulously abiding" by state and federal constitutional provisions regarding searches and seizures? And why did Chief Parker promise that his officers would work within the "framework of limitations" imposed by the law of search and seizure only so long as "the Exclusionary Rule is the law of California"? ${ }^{50}$

With the possible exception of Commissioner Murphy's comments on the impact of Mapp, is there any more persuasive testimony of the need for the exclusionary rule than Chief Parker's reaction to Cahan?

In his 1955 article, Professor Waite quotes from a letter to him from then Dean of the University of California School of Criminology, Orlando W. Wilson, who later would become Chief of the Chicago Police Department. The letter, written shortly before the Cahan case was decided, assures Waite that "[i]n respect of police training" (including instruction on "legal restrictions imposed on the police for the purpose of protecting individual rights"), not one of the states whose courts exclude illegally seized evidence "equals two nonexclusion states: California, the most progressive of all in police training, and New York, an early leader in the field." 51 All I can say is that Dean Wilson badly misled Professor Waite.

In addition to the statements made by Chiefs Murphy, Parker and others quoted above, consider Chief Judge Roger Traynor's explanation of why he (and his colleagues) became convinced of the need for the exclusionary rule in California:

My misgivings about [the admissibility of illegally seized evidence] grew as I observed that time after time [such evidence] was being offered and admitted as a routine procedure. It became impossible to ignore the corollary that illegal searches and seizures were also a routine procedure subject to no effective deterrent.... It was one thing to condone an occasional constable's blunder.... It was quite another to condone a steady course of illegal police procedures that deliberately and flagrantly violated the Constitution of the United States as well as the state constitution. ${ }^{52}$
49. Id. at 131 .
50. Id.
51. Waite (1955), supra note 1, at 194 n.77.
52. Roger J. Traynor, Mapp v. Ohio at Large in the Fifty States, 1962 DuKE L.J. 319, 322. 
Consider, too, Edward Barrett's description of the state of affairs in California before the Cahan decision was handed down. A California (Berkeley) law professor at the time, Barnett was known to be more sympathetic to the needs and interests of the police than most academics. Therefore, his comments are especially stinging:

[Prior to the adoption of the exclusionary rule in California] the police were under no substantial pressure to seek clarification of [the rules governing arrest, search and seizure]. The issue of legality became crucial so seldom that the police had, in effect, broad discretion in determining the procedure to follow ....

[T]he California situation was most unsatisfactory.... The possibilities of the situation improving appeared slight. Law enforcement groups preferred the ambiguity of [ill-defined and] seldom litigated rules and had no real incentive to take the risks involved in seeking legislative action. And there was little evidence that other groups would take the initiative. $^{53}$

Many police chiefs were too cautious (or too bewildered) to make any comments regarding Mapp. But a young Philadelphia assistant district attorney (and a future U.S. Senator), Arlen Specter, made it clear that, in Pennsylvania too, tort remedies, criminal prosecutions and internal police discipline had little or no effect. He announced that Mapp had "revolutionized" police practice and prosecution procedures in the many states that had been admitting illegally seized evidence. ${ }^{54}$ Indeed, he went so far as to call Mapp "the most significant event in criminal law since the adoption of the fourteenth amendment." 55

Mr. Specter, too, seemed to confuse the content of the law of search and seizure (which proponents of the exclusionary rule need not, and have not always, defended) with the exclusionary rule - a remedy, a rule that "merely states the consequences of a breach of

53. Edward L. Barrett, Jr., Exclusion of Evidence Obtained by Illegal Searches - A Comment on People v. Cahan, 43 CAL. L. REV. 565, 577, 587 (1955).

54. Arlen Specter, Mapp v. Ohio: Pandora's Problems for the Prosecutor, 111 U. PA. L. Rev. 4, 4 (1962) (emphasis added). As the New York City Police Commissioner had done, one Pennsylvania judge likened Mapp to a natural disaster - a " 'hurricane' which 'swept over our fair land last June.' " Id. at 4 (quoting Commonwealth v. One 1955 Buick Sedan, $198 \mathrm{~Pa}$. Super. 133, 135 (Pa. Super. Ct. 1962)). Another Pennsylvania judge, presumably not a Michigan law school graduate, "was so surprised by the Mapp holding that he said it applied only to Ohio so far as he was concerned until the Pennsylvania appellate courts told him otherwise." Id. at 4-5.

55. Id. at 4 . 
whatever principles might be adopted to control law enforcement officers. ${ }^{, 56} \mathrm{Mr}$. Specter warned:

There can be no doubt that the Mapp decision has significantly impaired the ability of the police to secure evidence to convict the guilty....

The law abiding citizens who must walk on some Philadelphia streets at two o'clock in the morning would doubtless prefer to be subjected to a search, without any cause, and have the police do the same to the man standing idly at a corner; but that cannot be done under Mapp. ${ }^{57}$

In Minnesota, however, the pattern of law enforcement responses to imposition of the exclusionary rule was broken. Another future U.S. Senator, and a future Vice President as well, Minnesota's young Attorney General, Walter Mondale, reminded an assemblage of distressed Minnesota officers that "[t]he language of the Fourth Amendment is identical to the [search and seizure provision] of the Minnesota State Constitution" and that "the Mapp case did not alter one word of either the state or national constitutions." ${ }^{8}$ Mondale continued:

[Mapp] does not reduce police powers one iota. It only reduces potential abuses of power. The adoption of the so-called "exclusionary rule" does not affect authorized police practices in any way. What was a legal arrest before, still is. What was a reasonable search before still is ....

The very fact that these [post-Mapp search and seizure] institutes are being held is eloquent testimony ... of the basic wisdom of the Court's decision. We are doing today, because of the Court's ruling, what we should have done all along. We are studying ways in which we can bring our police methods and procedures into harmony with the constitutional rights of the people we serve. ${ }^{59}$

What Mondale said, in effect, was that if the police feared that the evidence they were acquiring in their customary manner would now be excluded by the courts, they must have been unmindful of the socalled alternative remedies to the exclusionary rule all these years and they must have been violating the guarantee against unreasonable search and seizure all along. That, I think, is the hard truth.

56. Monrad G. Paulsen, The Exclusionary Rule and Misconduct by the Police, $52 \mathrm{~J}$. CRIM. L., CRIMINOLOGY \& POLICE SCI. 255, 255 (1961) (written on the eve of Mapp).

57. Specter, supra note 54 , at 42.

58. Walter Mondale, The Problem of Search and Seizure, BENCH \& B. MINN., Feb. 1962, at 16 .

59. Id. at 16,17 . 
When, some twenty years ago, I engaged in an exclusionary rule debate with Judge Malcolm Wilkey, he stunned me by blaming the failure to develop meaningful alternatives to the exclusionary rule on the exclusionary rule. The police "are not going to investigate and discipline their own men, and thus sabotage prosecutions," he warned, "[s]o long as we keep the rule." ${ }^{.60}$ On the other hand, he predicted, abolishing the exclusionary rule would lead to "experimentation" "in the laboratories of our 51 jurisdictions" "with various possible alternatives promising far more than the now discredited exclusionary rule." 61

This argument has several flaws. First, the fear of "sabotaging" criminal prosecutions in no way inhibits law enforcement administrators from disciplining officers who conduct unlawful searches that turn up nothing incriminating. Second, there are large areas of police activity (such as illegal detentions and unnecessary destruction of property) that do not produce any incriminating evidence and thus do not result in criminal prosecutions. Whatever the reason for the failure to discipline officers for misconduct in these instances, it cannot be the existence of the exclusionary rule.

Opponents of the exclusionary rule seem to think that they make a powerful argument against the rule when they point out that the rule does not operate if there is no illegally seized evidence to exclude. ${ }^{62}$ Of

60. Malcolm Richard Wilkey, The Exclusionary Rule: Why Suppress Valid Evidence?, 62 JudiCATURE 215, 218 (1978). At the time Wilkey was a judge on the U.S. Court of Appeals for the District of Columbia Circuit.

Judge Wilkey claimed that so long as the exclusionary rule was on the books, the development of meaningful alternatives would be inhibited because, inter alia, utilization of such alternatives would sabotage pending criminal prosecutions. Professor Amar blames inadequate tort remedies on the exclusionary rule for another reason. He seems to say that by "render[ing] the Fourth Amendment contemptible in the eyes of judges and citizens" the exclusionary rule has caused the public to "lose respect for the Fourth Amendment" itself and thus to lose interest in developing any effective remedy for its violation. Amar, supra note 21, at 799. However, this argument "ignores history," as pointed out in Steiker, supra note 3 , at 849 ; it overlooks the fact that no meaningful alternative to the exclusionary rule developed in any of the many states that admitted illegally seized evidence prior to Mapp. See infra text accompanying note 65 .

61. Wilkey, supra note 60 , at 232. Chief Justice Burger was even more sanguine about abolishing the exclusionary rule. A return to the days when illegally seized evidence was admissible, he predicted, "would inspire a surge of activity towards providing some kind of statutory remedy for persons injured by police mistakes or misconduct." Stone v. Powell, 428 U.S. 465, 501 (1976) (Burger, C.J., concurring). Earlier, although forcefully attacking the exclusionary rule, the Chief Justice had "hesitate[d] to abandon it until some meaningful substitute is developed." Bivens v. Six Unknown Named Agents, 403 U.S. 388, 415 (1971) (Burger, C.J., dissenting). I submit he was right the first time.

62. See, e.g., Akhil Reed Amar, Against Exclusion (Except to Protect Truth or Prevent Privacy Violations), 20 HARV. J.L. \& PUB. POL'Y 457, 463-64 (1997) [hereinafter Amar, Against Exclusion] ("If the police know you are innocent and just want to hassle you because of your race, your sex, your politics, and the search — predictably - finds no evidence, the exclusionary rule is no deterrent whatsoever. It is no help for you at all."). 
course it does not operate in such a situation. But why must it be an either/or proposition? Nothing prevents the use of tort remedies against the offending officers or police department sanctions against them "simultaneously with the use of the exclusionary rule." all, as Kenneth Pye once observed, "[n]o proponent of the exclusionary rule has suggested that it should act in isolation." 64

Still another response to Judge Wilkey, as I noted at the time of my debate with him, is to recall some modern history:

[F]or many decades, a majority of the states had no exclusionary rule but none of them developed any meaningful alternative. Thirty-five years passed between the time the federal courts adopted the exclusionary rule and the time Wolf was decided in 1949, but none of the 31 states which still admitted illegally seized evidence had established an alternative method of controlling the police. Twelve more years passed before Mapp imposed the rule on the state courts, but none of the 24 states which still rejected the exclusionary rule had instituted an alternative remedy. This half-century of post-Weeks "freedom to experiment" did not produce any meaningful alternative to the exclusionary rule anywhere. ${ }^{65}$

A forceful critic of the exclusionary rule, Christopher Slobogin, argues that the pre-Mapp failure to create tort remedies and other "direct sanctions" as alternatives to the exclusionary rule is consistent with the law prior to the 1960s, when there were "virtually no remedies for any constitutional criminal rights...."66 "Now, however," he maintains, "Mapp has gotten people used to thinking there should be a remedy for the Fourth Amendment." ${ }^{17}$ This claim would have been a good deal more plausible if it had been made one or two years after Mapp rather than forty years later ${ }^{68}$

Dissenting in the Bivens case, Chief Justice Burger urged Congress to develop an administrative or quasi-judicial remedy, outlining in some detail what such a remedy would look like.$^{69}$ That was ten years (1966)

63. A. Kenneth Pye, Charles Fahy and the Criminal Law, 54 GEO. L.J. 1055, 1072

64. Id.

65. Yale Kamisar, The Exclusionary Rule in Historical Perspective: The Struggle to Make the Fourth Amendment More than "an Empty Blessing," 62 JUDICATURE 337, 346 (1979) (footnotes omitted).

66. Slobogin, supra note 3, at 445 n.369.

67. Id.

68. Moreover, it is not at all clear to me that, as Professor Slobogin asserts, people have become accustomed to the view that there should be a remedy for a violation of the Fourth Amendment. It strikes me that people have become accustomed to complaining about criminals going free on "technicalities" without thinking, or caring much, about direct sanctions on the police. Indeed, two footnotes after his earlier assertion, Slobogin recognizes that "perhaps our society does not want full enforcement of the Fourth Amendment." $I d$. at 445 n.371. Even that strikes me as an understatement.

69. Bivens v. Six Unknown Named Agents, 403 U.S. 388, $422-23$ (1971) (Burger, C.J., dissenting). 
after the Mapp case and more than thirty years ago. In 1970 (Dallin Oaks) $^{70}$ and in 1981 (Richard Posner), ${ }^{71}$ two more critics of the exclusionary rule writing in the post-Mapp era, called attention to the need for effective tort remedies against the police. Once again, however, few, if any, lawmakers seemed to be listening.

About as many fortified tort remedies and other alternatives to the exclusionary rule have been proposed in the forty years since Mapp was decided as were proposed in the forty years before that landmark case was handed down. ${ }^{72}$ Yet the success rate has been the same. Zero.

One exasperated critic of the exclusionary rule, the late Joseph Grano, found it "difficult to believe that we are so intellectually impoverished ... that we lack the capability of devising an effective alternative approach [to the exclusionary rule]."73 The problem, however, is not a lack of imagination or intellectual capacity. Rather it is a lack of political will.

As Tracey Maclin has reminded us, ${ }^{74}$ ever since the 1930s, commentators have been underscoring the inadequacy of existing tort remedies against transgressing police and proposing what are now called "fortified" tort remedies. ${ }^{75}$ But nothing has come of any of these proposals. Why should we expect similar proposals made in our day ${ }^{76}$ to fare any better?

70. Dallin H. Oaks, Studying the Exclusionary Rule in Search and Seizure, 37 U. CHI. L. REV. 665, 756-57 (1970).

71. Richard A. Posner, Rethinking the Fourth Amendment, 1981 SUP. CT. REV. 49, 68.

72. See infra note 84 .

73. Joseph D. Grano, Introduction - The Changed and Changing World of Constitutional Criminal Procedure: The Contribution of the Department of Justice's Office of Legal Policy, 22 U. MICH. J.L. REFORM 395, 413 (1989).

74. Maclin, supra note 3, at 60 n.289.

75. See Jerome Hall, The Law of Arrest in Relation to Contemporary Social Problems, 3 U. CHI. L. REV. 345 (1936); William T. Plumb, Jr., Illegal Enforcement of the Law, 24 CORNELL L.Q. 337 (1939). Even the 1955 proposals by Barrett, supra note 53, at 592-95, and Caleb Foote, Tort Remedies for Police Violations of Individual Rights, 39 MINN. L. REV, 493 (1955), brand new when I entered teaching, are now almost a half-century old.

The overwhelming consensus is that, as they presently exist (and as they have long existed), civil suits against transgressing police officers, criminal prosecutions against them, internal police discipline, and review boards are woefully inadequate remedies. The classic article is Foote, supra. For the more recent literature, see Amsterdam, supra note 23, at 37879, 429-30; Maclin, supra note 3, at 59-65; Daniel J. Meltzer, Deterring Constitutional Violations by Law Enforcement Officials: Plaintiffs and Defendants as Private Attorneys General, 88 Colum. L. REV. 247, 284-86 (1988); Pierre J. Schlag, Assaults on the Exclusionary Rule: Good Faith Limitations and Damage Remedies, 73 J. CRIM. L. \& CRIMINOLOGY 875, 907-13 (1982); and William A. Schroeder, Deterring Fourth Amendment Violations: Alternatives to the Exclusionary Rule, 69 GEO. L.J. 1361, 1386-1410 (1981).

76. See infra note 84; see also infra text accompanying note 86 . 
Is there any reason to think that today's or tomorrow's politicians are, or will be, any less afraid of being called "soft on crime" or any more interested in protecting people under investigation by the police than the politicians of any other generation $?^{77}$ Is there any basis for believing that the lawmakers of our day are any more ready and willing than their predecessors to invigorate tort remedies (or administrative or criminal remedies) against the police for the benefit of "criminals" or those suspected of being criminals? ${ }^{78}$

A dramatic illustration of the political power possessed by the police and their allies appears in a new book by Welsh White. After many allegations that a police commander (John Burge) and the detectives who worked under him had been "torturing" suspects into confessing, the Chicago police department finally became convinced that at least some of these charges were true. ${ }^{79}$ To make matters worse, ten Illinois prisoners on death row (known as the "death row ten" or the "John Burge ten") maintained that Commander Burge and his men had resorted to torture in extracting confessions from them, too. ${ }^{80}$

"In the wake of the controversy surrounding the [aforementioned] torture cases," reports Professor White, "the Illinois legislature considered and at one point seemed inclined toward adopting a statute that would require the police to video- or audiotape interrogations of suspects in most cases." ${ }^{\prime 1}$ What happened?

77. "If anything," observes Steiker, "the escalating public hysteria over violent crime from the 1960 s through the present makes it even more "politically suicidal' today to support restrictions on police behavior than it was before 1961." Steiker, supra note 3, at 850 (footnote omitted). The quoted phrase comes from Amsterdam, supra note 23, at 379: "[T]here will remain more than enough crime and fear of it in American society to keep our legislatures from the politically suicidal undertaking of police control."

See also SASHA ABRAMSKY, HARD TIME BluES: How POLITICS BUILT a PRISON NATION 205 (2002): "[B]y the mid-1990s . . the politics around crime and drug abuse had been largely reduced to a battle of sound bites: who could successfully communicate their toughness to voters clamoring for harsher punishments."

78. Too many politicians (and lay persons, too), I am afraid, share former Attorney General Edwin Meese's view that "the thing is, you don't have many suspects who are innocent of a crime .... If a person is innocent of a crime, then he is not a suspect." Susan Bandes, "We the People" and Our Enduring Values, 96 MiCH. L. REV. 1376, 1379 (1998) (book review) (omission in original) (quoting Reagan Seeks Judge with "Traditional Approach," U.S. NEWS \& WORLD REP., Oct. 15, 1985, at 67).

79. Welsh S. White, Miranda's Waning Protections 128-36 (2001). As the result of a civil lawsuit brought by one of Burge's victims, a police investigator looked into charges against the commander and concluded that for a period of more than ten years, he and the detectives under him had used abusive interrogation practices. Id. at 130. In 1993, after a police board determined that Burge had tortured the person who brought the lawsuit against him, the commander was dismissed from the police force. Id.

By "torture," I mean suffocating a suspect with a typewriter cover, administering an electric shock to his genitals, hanging him by handcuffs for several hours, and playing "Russian roulette" with a police weapon in the suspect's mouth. Id. at 129.

80. Id. at $130-31$.

81. Id. at 136. 
"Before the bill could be passed," the "law enforcement community" made plain its opposition. "Among other things," it issued a "Legislative Alert" claiming that "mandatory videotaping provides new 'hoops and hurdles' for law enforcement and 'reflects major expansion of the rights of the accused at the expense of crime victims, public safety and law enforcement.' " 82 The result? The bill's sponsors declined "to introduce it for a vote by the full House of Representatives." 83

Illegal arrests and unlawful searches and seizures are typically less often characterized by violence and brutality than are impermissible police interrogation methods. Therefore, lawless arrests and searches are less likely to attract the press or arouse the community. (Moreover, unlike the Chicago torture cases, violations of the Fourth Amendment do not raise doubts about a defendant's innocence.) If the law enforcement community can squelch legislative reform efforts in the confessions area as peremptorily as it did in the wake of the Burge scandal, how much trouble will the police have defeating search and seizure proposals that impose direct sanctions on them?

Nevertheless, new legislative proposals for direct sanctions against lawless police, e.g., tort remedies, administrative remedies, internal disciplinary systems, keep coming (usually accompanied by a sharp attack on the desirability and efficacy of the exclusionary rule) ${ }^{84}$

Christopher Slobogin's proposal, worthy of note because it is the subject of a long, well-written, heavily documented article, ${ }^{85}$ is illustrative. At one point, Professor Slobogin states:

82. Id. (footnote omitted). Why videotaping of police interrogation of suspects would greatly expand suspects' rights and how such videotaping would impair public safety was not made clear.

83. Id. (footnote omitted).

84. See, e.g., Amar, First Principles, supra note 3, at 811-16; Randy E. Barnett, Resolving the Dilemma of the Exclusionary Rule: An Application of Restitutive Principles of Justice, 32 EMORY L.J. 937, 969-80 (1983); Robert Batey, Deterring Fourth Amendment Violations Through Police Disciplinary Reform, 14 AM. CRIM. L. REV. 245, 252-56 (1976); Robert P. Davidow, Criminal Procedure Ombudsman Revisited, 73 J. CRIM. L. \& CRIMINOLOGY 939 (1982); L. Timothy Perrin et al., If It's Broken, Fix It: Moving Beyond the Exclusionary Rule, 83 IOWA L. REV. 669, 743-54 (1998).

Perhaps the most interesting proposal in recent years is one by Donald Dripps, "that courts should begin to experiment with suppression orders that are contingent on the failure of the police department to pay damages set by the court." Donald Dripps, The Case for the Contingent Exclusionary Rule, 38 AM. CRIM. L. REV. 1, 2-4 (2001). According to Professor Dripps, the damages should be set so as to "leave the government indifferent between exclusion and damages in the ordinary case, yet still free to pay the damages when the illegality turns up an exceptionally culpable or dangerous crime." Id. at 3 . However, I share the view of George C. Thomas III, that "[j]udges trained in the common law method are unlikely to take it upon themselves to adopt such a complex, legislative-type, global solution to a so-far unyielding problem" and are unlikely to be "institutionally capable of crafting the discerning solution that Dripps envisions." George C. Thomas III, Judges Are Not Economists and Other Reasons to be Skeptical of Contingent Suppression Orders: $A$ Response to Professor Dripps, 38 AM. CRIM. L. REV. 47, 48 (2001).

85. Slobogin, supra note 3. 
[A] regime that directly sanctions officers and their departments is preferable to the [exclusionary] rule. Although there are many versions of such a regime, it should have several core components: (1) a liquidated damages/penalty for all unconstitutional actions, preferably based on the average officer's salary; (2) personal liability, at the liquidated damages sum, of officers who knowingly or recklessly violate the Fourth Amendment; (3) entity liability at the liquidated damages sum, for all other violations; (4) state-paid legal assistance for those with Fourth Amendment claims; and (5) a judicial decisionmaker. ${ }^{86}$

To his credit, Professor Slobogin recognizes that his scheme may not be politically feasible:

There is no doubt that the proposed system would be expensive.... Attorneys for both sides would have to be paid and a special bench would have to be created. Police departments would be accountable for damages and would incur costs in improving training programs and increasing job qualification requirements. Departments might also have to spend more on salaries, if fear of liability drives some applicants away. 87

When I think about Professor Slobogin's proposal for a formidable tort remedy against transgressing police, I am reminded of Donald Dripp's comment about a similar legislative proposal: "Who would be in favor of such legislation? Law professors and civil libertarians. Who would oppose it? Any politician who wants to be seen as a friend of the police." 88

Suppose Congress were to enact a tort remedy that included many features of Professor Slobogin's proposal. Suppose, for example, that such legislation would provide state-paid legal assistance for all persons who claim their "right to be secure" was violated by the police; nontrivial liquidated damages for all violations of the Fourth Amendment (say $\$ 10,000$ or $\$ 15,000$ for every illegal arrest and

\section{Id. at 442 .}

87. Id. at 444 . Slobogin is well aware that surveys of the police indicate that they prefer the exclusionary rule over a damages remedy, police department sanctions, or other forms of direct sanction. $l d$. at 392 . He assumes this is so because the exclusionary rule "imposes the fewest restrictions on their actions." Id. But it may be more complicated than that.

Some twenty years after Mapp, Milton Loewenthal (who taught police officer students at John Jay College of Criminal Justice of the City University of New York at the time) conducted what I believe is the most comprehensive study of police attitudes toward the exclusionary rule. Professor Loewenthal interviewed many police officers on all levels as well as many of his own police officer students. According to Professor Loewenthal, the police "have great difficulty believing that standards can have any real meaning if the government can profit from violating them." Milton A. Loewenthal, Evaluating the Exclusionary Rule in Search and Seizure, 49 UMKC L. REV. 24, 39 (1980). Moreover, Loewenthal found "strong evidence that, regardless of the effectiveness of direct sanctions, police officers could neither understand nor respect a Court which purported to impose constitutional standards on the police without excluding evidence obtained in violation of those standards." Id. at 29.

88. Dripps, supra note 44 , at 1619. 
$\$ 25,000$ or $\$ 35,000$ for every unlawful search of the home); and thirtyfive or forty percent of the offending officer's annual salary for each and every intentional or reckless violation of the Amendment he committed. ${ }^{89}$ Suppose, in short, Congress enacted a perfect tort remedy or one as perfect as could be (from the point of view of the victim of police misconduct at any rate). Would I go along with abolition of the exclusionary rule in favor of such a remedy?

I cannot help recalling how the late Charles Black responded when asked whether he would withdraw his opposition to the death penalty if he were sure that the system of capital punishment "were being administered with perfect fairness." like asking me: "Would you take trains if the earth were made flat, or would you fear that they would run off the edge?"91

89. Id. at 1618-19. Professor Dripps may not be willing to call a tort remedy against the police a perfect one unless it includes a provision that "either party may introduce polygraph evidence and the failure of the opposing party to introduce such evidence." Id. at 1619.

90. Charles L. Black, Jr., The Death Penalty Now, 51 TUL. L. REV. 429, 445 (1977).

91. Id. This was not Professor Black's complete answer to the question he has often been asked. (He made it clear he would still be opposed to capital punishment.) Nor is it the complete answer to the question I have sometimes been asked.

After pinching myself a few times, to make sure I wasn't dreaming, I would applaud the enactment into law of the "perfect tort remedy" against offending police officers. I would also support the enactment of Professor Slobogin's plan, which looks quite promising. I would be willing to replace the exclusionary rule with the new legislation in most instances. As Professor Slobogin himself prefers, however, I would want to retain the exclusionary rule for flagrant or egregious violations of the Fourth Amendment. See Slobogin, supra note 3, at 440-41.

I should add that I have little doubt that the present Court would uphold a federal statute adopting Professor Slobogin's proposal as an adequate alternative to the exclusionary rule. The Court that decided Mapp seemed to consider the search and seizure exclusionary rule a constitutional requirement. See Allen, supra note 35, at 23-24, 26; Yale Kamisar, Does (Did) (Should) the Exclusionary Rule Rest on a "Principled Basis" Rather than an "Empirical Proposition"?, 16 CREIGHTON L. REV. 565, 623-27 (1983) [hereinafter Kamisar, Exclusionary Rule]; Schlag, supra note 75, at 884-86. The post-Warren Court, however, no longer does. See especially United States v. Leon, 468 U.S. 897, 906 (1984); United States v. Calandra, 414 U.S. 338, 348 (1974); see also LAFAVE, supra note 16, at 2122; Susan R. Klein, Identifying and (Re)Formulating Prophylactic Rules, Safe Harbors, and Incidental Rights in Constitutional Criminal Procedure, 99 MiCH. L. REV. 1030, 1048-49 (2001). The exclusionary rule must now be regarded as a "prophylactic rule" or a first cousin to prophylactic rules like Miranda. Professors LaFave, Israel, and King put it in the "prophylactic rule" category, i.e., describe it as a "prophylactic remedial measure." WAYNE R. LAFAVE, JEROLD H. ISRAEL \& NANCY J. KING, CRIMINAL PROCEDURE \& 2.9(e) at 67475 (2d ed. 1999). Professor Klein calls the search and seizure exclusionary rule a " 'constitutional incidental right,' a judicially-created procedure determined by the Court as the appropriate relief for the violation of an explicit or 'true' constitutional rule or a prophylactic rule." Klein, supra, at 1033 . These commentators may differ about the label, but they agree that Congress is free to replace the exclusionary rule with a suitable substitute.

Professor Slobogin seems to think that there is no harm in calling for the abolition of the exclusionary rule, and bashing it in the process, so long as its abolition is conditioned on enactment of an effective alternative remedy. I am not at all sure.

As Susan Bandes has pointed out, a member of Congress (or a state legislator, or a Supreme Court Justice for that matter) may not realize, or may not care, that an article or a speech (or testimony before a Senate committee) strongly criticizing the exclusionary rule was accompanied by a fortified tort remedy or administrative remedy designed to take the 
C. One does not happily charge the judiciary with responsibility for the country's burden of crime, but the responsibility does in fact exist. Judges, though they may not encourage crime, interfere with its prevention in various ways. They deliberately restrict police efficiency in the discovery of criminals. They exempt from punishment many criminals who are discovered and whose guilt is evident. ${ }^{92}$

Professor Waite was hardly the only critic of the exclusionary rule who asserted or assumed that the rule had a large impact on the apprehension and conviction of criminals. Chief Justice Warren Burger maintained that "this Draconian" remedy exacts "exorbitant costs from society" 93 and results in "the release of countless guilty criminals." "94 And future Chief Justice Rehnquist viewed Mapp as a case that "brought to bear in favor of accused murderers and armed

rule's place. Bandes, supra note 78 , at 1407 . The Congressman, state legislator, or Supreme Court Justice may be much more interested in, or impressed by, the attack on the rule than on the need for a meaningful alternative.

As Tracy Maclin has noted, Wigmore was only the first in a line of commentators who attacked the exclusionary rule, but then professed "his love and affection for the Fourth Amendment by proposing a remedy that would never materialize in the real world." Maclin, supra note 3, at 55. Unfortunately, most of us seem to remember various commentators' assaults on the exclusionary rule a good deal better than we do the alternative remedies these commentators offered in its place.

Every student of the Fourth Amendment is familiar with Wigmore's attack on the exclusionary rule. See John H. Wigmore, Using Evidence Obtained by Illegal Search and Seizure 8 A.B.A. J. 479 (1922). Few, however, know - and still fewer take seriously - the alternative remedy he offered: send for the overzealous police officer and send him to jail for thirty days for "contempt of the Constitution." Id. at 484. (Imagine the uproar if three or four officers were sent to jail for "contempt of the Constitution." Imagine how many judges who have to run for re-election would avail themselves of this remedy.)

Some people probably still remember Judge Wilkey's forceful attack on the exclusionary rule. See Wilkey, supra note 60 . But how many remember, or take seriously, the alternative remedy he proposed? I debated him some twenty years ago, and I did not remember what alternative he offered. I had to look it up: a "mini-trial" of the offending police officer, one that would take place after the main criminal case. Id. at 231.

Perhaps the most widely-cited attack on the exclusionary rule - and it is a scathing attack - is Dallin Oaks' article. See Oaks, supra note 70. This article is almost always cited for its multi-faceted criticism of the exclusionary rule, but almost never for its word of caution about getting rid of the rule. Very few people remember, if they ever knew, that on the next-to-last-page of his ninety-two-page article Professor Oaks warns that "[d]espite [its] weaknesses and disadvantages, the exclusionary rule should not be abolished until ... [it is] replaced by an effective tort remedy." $I d$. at 756 . Oaks was well aware that no such remedy existed at the time, but he discussed various ways in which such a remedy could be made more effective. An effective tort remedy, he pointed out, a decade after Mapp - and more than thirty years ago - is "long overdue." Id. at 757.

92. Waite (1955), supra note 1, at 169.

93. Stone v. Powell, 428 U.S. 465, 500 (1976) (Burger, C.J., concurring)

94. Bivens v. Six Unknown Named Agents, 403 U.S. 388, 416 (1971) (Burger, C.J., dissenting). 
robbers a rule which had previously largely had an application to bootleggers and purveyors of stolen lottery tickets." 95

In his much-discussed 1994 assault on the exclusionary rule, Akhil Amar, too, implies that the rule has a considerable adverse impact on police efforts to bring murderers and other violent criminals to book. In one two-and-a-half page segment alone, Professor Amar asks or discusses six times whether "the murderer's bloody knife" or "the bloody knife" should be admitted into evidence or excluded and whether it "would have come to light anyway." I6 Immediately thereafter, working with another hypothetical, Amar discusses whether Bob's "bloodstained shirt" should be "introduced as evidence in Bob's murder trial." 97

"The most careful and balanced assessment conducted to date of all available empirical data," 98 is a study by Thomas Davies that indicates that "the general level of the rule's effects on criminal prosecutions is marginal at most." 99 The impact of the rule is greater

95. California v. Minjares, 443 U.S. 916, 927 (1979) (Rehnquist, J., dissenting from denial of stay) (emphasis added). More recently, another critic of the exclusionary rule, Judge Stephen Markman, has declared it "indisputable that considerable numbers of people have been murdered, raped, assaulted and terrorized as a direct result of the exclusionary rule." Stephen J. Markman, Six Observations on the Exclusionary Rule, 20 HaRV. J.L. \& PUB. POL'Y 425, 432-33 (1997).

96. Amar, First Principles, supra note 3, at 793-95.

97. Id. at 795-98. Professor Amar mentions "Murderer Bob" or his "bloodstained shirt" three times in a four-page segment.

98. LAFAVE, supra note $16, \S 1.3(\mathrm{c})$, at 58 (praising Professor Davies' study).

99. Davies, A Hard Look, supra note 6, at 622 (emphasis omitted).

Twelve years after he published his study on the "costs" of the exclusionary rule, Professor Davies told the Senate Judiciary Committee that if the research he had done in the $1980 \mathrm{~s}$ "were repeated today, there is every reason to think that the 'lost arrest' rate would be even lower, because search law has been relaxed even further since that date." The Jury and the Search for the Truth: Hearing on S.3 Before the Senate Comm. on the Judiciary, 104th Cong., 143 (1995) [hereinafter Hearings] (statement of Professor Thomas Davies). Davies told the committee that "[t]he Court ha[d] made it extremely easy for police to claim the victim of a search 'consented' to it - which is undoubtedly the ground that accounts for the largest number of legal searches." Id. at 141. Citing, inter alia, California v. Greenwood, 486 U.S. 35 (1988) (police examination of sealed garbage bags placed on curb for pickup, not a "search"), and Florida v. Riley, 488 U.S. 445 (1989) (observations from police helicopter hovering over fenced-in backyard not a "search"), Davies noted that the Court had narrowed what police activity constituted a "search" and thus what police activity had to comply with the Fourth Amendment. See id. at 141. For other examples of what Davies called "police-friendly" or "government-friendly" Supreme Court decisions in recent years, see $i d$. at 141-43. See also the discussion of "bright-line" or "safe harbor" rules, infra note 114.

If Whren $v$. United States, 517 U.S. 806 (1996) (holding that the police can stop a motorist where there are adequate grounds to believe some traffic violation has occurred, even though the stop is pretextual), had been decided a year earlier, I venture to say that Professor Davies would have focused on that case in his testimony. As William J. Stuntz recently observed:

In a world ... where routine traffic offenses count as crimes, the requirement of probable cause to arrest may mean almost nothing. Officers can arrest for a minor offense everyone violates the traffic rules - in order to search or question a suspect on a major one. 
for particular crimes, such as felony drug offenses, "the prosecution of which depends heavily on physical evidence." 100 Indeed, "[t]he most striking feature of the data is the concentration of illegal searches in drug arrests (and possibly weapons possession arrests) and the extremely small effects in arrests for other offenses, including violent crimes." ${ }^{101}$ For example, "[t]he statewide California data show that less than $0.3 \%$ (fewer than three in 1000) of arrests for all nondrug offenses are rejected by prosecutors because of illegal searches, and there are even smaller effects for the most serious violent crimes."102

The data also reveals that the exclusion of murderers' and rapists' "bloody knives" and "bloodstained shirts" is an exceedingly rare event: according to a five-year study of California data, illegal search and seizure problems were given as the reason for the rejection of only thirteen of more than 14,000 forcible rape arrests $(0.09 \%)$ and only eight of approximately 12,000 homicide arrests $(0.06 \%) .{ }^{103} \mathrm{~A}$ ninecounty, three-state study, involving some 7,500 cases, disclosed that "[n]one of the motions [to exclude evidence] granted... involved exceptionally serious cases such as murder, rape, armed robbery, or even unarmed robbery." 104

This allows arrests and searches of suspected drug dealers without any ex ante support for the suspicion, the very thing the probable cause standard is supposed to forbid.

William J. Stuntz, The Uneasy Relationship Between Criminal Procedure and Criminal Justice, 107 YALE L.J. 1, 3 (1997).

100. United States v. Leon, 468 U.S. 897,907 n.6 (1984).

101. Davies, A Hard Look, supra note 6, at 680. Davies estimates, on the basis of available data, that "the cumulative loss of drug arrests at all stages of felony processing in California is around 7.1\%." Id. at 681. In Leon, the Court states that "the cumulative loss due to nonprosecution ... of individuals arrested on felony drug charges is probably in the range of $2.8 \%$ to $7.1 \%$." 468 U.S. at 907 n.6.

102. Davies, A Hard Look, supra note 6, at 619.

103. See id. at 640,645. One may contend, as did Justice White for the Court in United States $v$. Leon, that the small percentages of cases lost because of the exclusionary rule "mask a large absolute number." 468 U.S. at 908 n.6 (emphasis added). But "raw numbers are not as useful for policy evaluation as percentages. In a system as large as the American criminal justice system... almost any nationwide measurement or estimate will look large if expressed in raw numbers." Davies, A Hard Look, supra note 6, at 670.

Moreover, what about cases lost for other reasons? Professor Dripps may have overstated the point somewhat, but not, I think, by very much when he observed: "For every prosecution aborted by the constitutional exclusionary rules, roughly a hundred founder because of numbingly prosaic procedural problems. The guilty go free primarily because justice takes too long and because the witnesses do not testify when the trial finally occurs." Donald Dripps, Beyond the Warren Court and Its Conservative Critics: Toward a Unified Theory of Constitutional Criminal Procedure, 23 U. MiCH. J.L. REFORM 591, 634-35 (1990).

104. Peter F. Nardulli, The Societal Cost of the Exclusionary Rule: An Empirical Assessment, 1983 AM. B. FOUND. RES. J. 585, 596 n.47 (emphasis added). (The three states were Illinois, Michigan and Pennsylvania.); see also Maclin, supra note 3, at 44. Consider, too, the testimony of E. Michael McCann, district attorney of Milwaukee, before the Senate Judiciary Committee. Mr. McCann told the Committee that although he had been the district attorney of Milwaukee for twenty-seven years, during which time he had "been involved in tens of thousands of prosecutions," he could not recall a single "murder case - 
Although he offered many reasons for scrapping the exclusionary rule, Dallin Oaks refused to make one argument against the rule that (to use a term popular at the time) the rule "handcuffs" the police in their pursuit of criminals:

The whole argument about the exclusionary rule "handcuffing" the police should be abandoned. If this is a negative effect, then it is an effect of the constitutional rules, not an effect of the exclusionary rule as the means chosen for their enforcement. Police officials and prosecutors should stop claiming that the exclusionary rule prevents effective law enforcement. In doing so they attribute far greater effect to the exclusionary rule than the evidence warrants, and they are also in the untenable position of urging that the sanction be abolished so that they can continue to violate the rules with impunity. ${ }^{105}$

I consider it noteworthy that Professor Oaks, the author of one of the most powerful attacks on the exclusionary rule, made what is in essence one of the favorite arguments of the rule's supporters. This argument, which has been called "[t]he classic response" of the rule's defenders, ${ }^{106}$ was well stated more than sixty years ago:

indeed, a homicide case - . . that we lost because of the fourth amendment." Hearings, supra note 99, at 97-98 (Statement of E. Michael McCann).

The impact of the exclusionary rule may be negligible in rape, homicide and other violent crime cases because Fourth Amendment problems rarely arise in such cases or because the police make special efforts to satisfy prescribed search and seizure standards in such cases. To a considerable, but unknown extent, however, the negligible effects of the exclusionary rule in these types of cases may reflect the reluctance of judges to grant the suppression motions of "serious criminals." Stephen Duke, Making Leon Worse, 95 YALE L.J. 1405,1408 n.33 (1986).

A decade ago, Myron Orfield interviewed some forty Chicago criminal court judges, public defenders and prosecuting attorneys. He reported that in a "heater case," "a big case that has the potential to arouse public ire if the defendant goes free" for a violation of the Fourth Amendment - the "quintessential heater is a murder case" - the elected judge is under enormous pressure to admit evidence obtained in an illegal search and will always, or almost always, find a way to do so. Myron W. Orfield, Jr., Deterrence, Perjury, and the Heater Factor: An Exclusionary Rule in the Chicago Criminal Courts, 63 U. COLO. L. REV. 75, 115-22 (1992). In Chicago (and undoubtedly in other places as well), most judges, at least those who have to run for reelection, seem to have unofficially adopted the substance of John Kaplan's proposal: carve out an exception to the exclusionary rule for "treason, espionage, murder, armed robbery and kidnapping by organized groups." John Kaplan, The Limits of the Exclusionary Rule, 26 STAN. L. REV. 1027, 1046 (1974). I consider this an unfortunate development for reasons I have spelled out elsewhere. See Yale Kamisar, "Comparative Reprehensibility" and the Fourth Amendment Exclusionary Rule, $86 \mathrm{MICH}$. L. REV. 1 (1987) [hereinafter Kamisar, Comparative Reprehensibility]. But see Stuntz, Virtues and Vices, supra note 3 , at 447 :

[T] he visibility of the criminal who walks away [because of the exclusionary rule] has an important benefit: it makes courts see the consequences of the constitutional rules they create for the police. The exclusionary rule is ... a way of limiting counter-majoritarian excess. Judges who write rules that prevent the capture of the occasional rapist are forced to see an occasional rapist walk away as a result of those rules. And the rest of us can see it, too. That may serve to rein in overly aggressive judicial lawmakers.

105. Oaks, supra note 70 , at 754.

106. Amar, First Principles, supra note 3, at 793. 
I have no fear that the exclusionary rule will handicap the detection or prosecution of crime. All the arguments that have been made on that score seem to me to be properly directed not against the exclusionary rule but against the substantive guarantee itself .... It is the rule, not the sanction, which imposes limits on the operation of the police. If the rule is obeyed as it should be, and as we declare it should be, there will be no illegally obtained evidence to be excluded by operation of the sanction. ${ }^{107}$

Akhil Amar, however, rejects the argument that setting criminals free is a cost of the Fourth Amendment itself, not the exclusionary rule. "Suppose," he responds, "the police could easily get a warrant, but fail to do so" and "the court goes on to exclude the bloody knife." 108 "The police could easily have obtained a warrant before the search, so the illegality is not a but-for cause of the introduction of the knife into evidence." 109

First of all, the case Professor Amar poses will not, as he asserts, arise "in many situations." 110 The government will almost never lose evidence for its failure to obtain a warrant because it almost never needs a warrant to conduct a search and it almost never uses one. "[A]lthough more frequent than in pre-Mapp days, obtaining a search

107. Statement of U.S. Senator Robert F. Wagner, 1 NEW YORK CONSTITUTIONAL CONVENTION, REVISED RECORD 560 (1938). For an even earlier statement of this argument, see Connor Hall, Evidence and the Fourth Amendment, 8 A.B.A. J. 646 (1922). For other versions of the same basic argument, see, e.g., Allen, supra note 35, at 34; Kamisar, Comparative Reprehensibility, supra note 104, at 47-48; and Stewart, supra note 30, at 1393.

108. Amar, First Principles, supra note 3, at 794.

109. Id. Although he is not happy about it, Professor Amar recognizes that the "inevitable discovery" exception to the exclusionary rule does not apply to the situation he poses. See id. at 794 n.137; Amar, Against Exclusion, supra note 62, at 462. Judge Frank Easterbrook put it well, I think, when he observed that in a situation where the police have probable cause, but do not, as they should, obtain a warrant, "what makes a discovery 'inevitable' is not probable cause alone ... but probable cause plus a chain of events that would have led to a warrant (or another justification) independent of the search." United States v. Brown, 64 F.3d 1083, 1085 (7th Cir. 1995). Otherwise, adds Judge Easterbrook, "the requirement of a warrant for a residential entry will never be enforced by the exclusionary rule." Id.

The "inevitable discovery" exception to the exclusionary rule permits the use of unlawfully obtained evidence if it "ultimately or inevitably would have been discovered by lawful means." Nix v. Williams, 467 U.S. 431, 444 (1984) (emphasis added). The exception does not apply simply because the police could have or might have obtained the evidence lawfully - simply because "the police had the capacity (which they did not exercise)" to proceed lawfully. 3 WAYNE R. LAFAVE, JEROLD H. ISRAEL, \& NANCY J. KING, CRIMINAL Procedure \& 9.3(e), at 354 (2d ed. 1999) (emphasis added). As the Court, per Justice Scalia, recently observed:

The fact that equivalent information could sometimes be obtained by other means does not make lawful the use of means that violate the Fourth Amendment. The police might, for example, learn how many people are in a particular house by setting up year-round surveillance; but that does not make breaking and entering to find out the same information lawful.

Kyllo v. United States, 533 U.S. 27, 35 n.2 (2001) (Scalia, J.)

110. Amar, First Principles, supra note 3, at 794. 
warrant is still a relatively rare phenomenon";111 "the vast majority of searches are now conducted without a warrant, yet they are regularly declared 'reasonable' by the Court."112 One category alone, warrantless searches incident to arrest, "outnumber[s] manyfold searches covered by warrants." in favor of the police (sometimes called "safe harbor" rules), especially in the context of automobiles, have further reduced the need for search warrants - indeed, have exempted from the warrant requirement virtually all searches outside of homes and offices. ${ }^{114}$

In most of the relatively few cases that illegally seized evidence is excluded, then, it will be because the police lacked sufficient information to make the search in the first place. So most of the time that illegally seized evidence is thrown out the basic point of the exclusionary rule's defenders is valid: the search should not have occurred in the first place - and would not have occurred if the police had obeyed the Fourth Amendment in the first place.

Moreover, posing a hypothetical case where the police "could easily have obtained a warrant, but fail[ed] to do so" is one thing; applying this hypothetical to the real world is something else. It will often be unclear whether police who have acted without a warrant could have obtained a warrant if they had applied for one. The fact that a judge is prepared to uphold a search after it has turned up incriminating evidence does not necessarily mean that a magistrate would have issued a warrant before the search was made. (In some instances it may not even mean that an officer thought he had enough

111. Richard VAN DUIZEND ET AL., THE SEARCH WARRANT PRocess: PRECONCEPTIONS, PERCEPTIONS, PRACTICES 17 (Nat'l Ctr. for State Courts, 1984).

112. Klein, supra note 91, at 1038; see also VAN DUIZEND ET AL., supra note 111, at 19.

113. TELFORd TAYLOR, Two STUdiEs IN CONSTITUTIONAL INTERPRETATION 48 (1969). And the percentage of arrests made pursuant to an arrest warrant is astonishingly small. For example, five years after Mapp, of 171,288 arrests made by the New York City police, "only 366 were made pursuant to an arrest warrant." MODEL CODE OF PREARraignment Procedure, Commentary at 493 n.5 (Official Draft 1975).

114. See Dripps, supra note 44, at 1607-08; William J. Stuntz, Warrants and Fourth Amendment Remedies, 77 VA. L. REV. 881, 921-22 (1991) [hereinafter Stuntz, Warrants]; see also in chronological order, Chambers v. Maroney, 399 U.S. 42 (1970) (holding that police do not need a warrant to search a car even though driver is in custody and car is immobilized); United States v. Robinson, 414 U.S. 218 (1973) (holding that as part of valid search incident to defendant's arrest, police may conduct warrantless search of containers in defendant's possession); New York v. Belton, 453 U.S. 454 (1981) (holding that police may conduct warrantless search of entire passenger compartment of arrested driver's car); United States v. Ross, 456 U.S. 798 (1982) (holding that where police have probable cause to believe that a car contains a controlled substance, they may conduct a warrantless search of entire vehicle, including trunk and containers found within vehicle); and California v. Acevedo, 500 U.S. 385 (1991) (holding that when police have probable cause to believe that a particular container in the vehicle (as opposed to the entire vehicle) contains contraband or evidence of crime, they may conduct warrantless search of particular container). "Safe harbor" rules, such as those cited above, in effect "permit searches without warrants that might be 'unreasonable' on their particular facts." Klein, supra note 91, at 1045. 
information to apply for a warrant.) "It must be much harder for a judge to decide that an officer had something less than probable cause to believe cocaine was in the trunk of a defendant's car when the cocaine was in fact there."115

Moreover, the fact that the application for a warrant is granted or rejected "before the officer knows what he will find in the place to be searched ... makes perjury somewhat harder, since the officer cannot so easily manufacture details consistent with a story he does not yet know." 116 One reason it is desirable for the police to seek warrants is that "they make officers record what they know before the search takes place, and thus make it harder for them to lie about what they knew when they testify at suppression hearings." "17

Almost all critics of the exclusionary rule assure us that they want to replace it with an effective "direct remedy" (such as a tort action against the offending officer, a criminal prosecution, or internal police discipline). The question, therefore, is not whether establishing the exclusionary rule would eliminate the so-called costs of the rule (guilty people going unpunished), but whether an alternative remedy would exact fewer "costs" than the exclusionary rule does. Professor Stuntz's observations should give proponents of alternative remedies pause to think again:

[T]he usual legal tools - damages, fines, criminal punishment - are likely to cause more harm than good if they are widely used. If an officer faces serious loss whenever he makes a bad arrest, he will make fewer bad arrests, but also many fewer good ones. The same is true, only more

115. Stuntz, Warrants, supra note 114 , at 912 , 913 ; see also Katz v. United States, 389 U.S. 347, 358 (1967) (quoting with approval from Beck v. Ohio, 379 U.S. 89, 96 (1964)) (Bypassing the warrant procedure " substitutes instead the far less reliable procedure of an after-the-event justification for the ... search, too likely to be subtly influenced by the familiar shortcomings of hindsight judgment." ").

116. Stuntz, Warrants, supra note 114, at 915 (emphasis omitted). A study of the Chicago criminal justice system discloses that "[j]udges and public defenders perceive perjury to be the major factor limiting the deterrent effect of the [exclusionary] rule." Orfield, supra note 104, at 98. Nevertheless, most people interviewed "believe that the exclusionary rule has dramatically improved police behavior and should be retained.... Today, while police often perjure themselves, they also, because of the exclusionary rule, often obey the Fourth Amendment." Id. at 132; see also Albert W. Alschuler, Fourth Amendment Remedies: The Current Understanding, in THE BILL OF RIGHTS: ORIGINAL MEANING AND CURRENT UNDERSTANDING 197, 199 (Eugene W. Hickok ed., 1991).

117. Stuntz, Warrants, supra note 114 , at 925 . Not only is it easier for an officer who made a search without a warrant to lie at the suppression hearing (because he knows the objective evidence before he testifies), but a "generally honest police officer may well be more willing to lie at a suppression hearing than in a warrant application, because at that point [he] knows the suspect is guilty, and that fact may make lying more palatable." $I d$. at 915 n.75 (emphasis added). 
so, if the law threatens the officer with jail for constitutional violations....

The temptation is to solve this problem by making the government, rather than the individual police officer, bear the immediate costs of legal liability. Unfortunately, that move solves nothing. Most police work for local governments, and most local governments operate under serious budget constraints. The effect of governmental damages liability for police misconduct mimics the effect of making individual officers pay damages: the locality has an incentive to reduce its liability by reducing the level of policing. ${ }^{18}$

If Professor Stuntz is right, and I think he is, if the exclusionary rule were to be replaced with a meaningful "direct remedy," drug offenders and other criminals would no longer be "released," but approximately the same number (or more) would no longer be illegally searched or arrested in the first place.

To be sure, we would not see the faces or know the names of the criminals who remained free because the police never searched or arrested them illegally. Nor would we know precisely what evidence the police wrongfully acquired, because the direct remedy would inhibit them from acquiring any evidence illegally. For these reasons, the "direct alternative remedy" would not "rub[] our noses" in the Fourth Amendment the way the exclusionary rule does. ${ }^{119}$ But beyond that, what would really change? (Perhaps we would start talking about the costs of the direct remedy or, better yet, the costs of the Fourth Amendment, rather than the costs of the exclusionary rule.)

D. To the simple citizen who hears of guilty men exempted from punishment by judicial decision it matters nothing what ulterior motive lies in the judicial mind. He knows only that the activities of a dope-peddler, a notorious numbers racketeer, a score of gun-toters, a counterfeiter, or a robber have not been considered wrongful enough by the judge to justify conviction. ${ }^{120}$

118. Stuntz, Virtues and Vices, supra note 3, at 445-46. But see Slobogin, supra note 3, at 444: "With an effective deterrent [other than the exclusionary rule] in place, police who lack probable cause will not necessarily give up; the more reasonable assumption is that they will simply get more cause." I fail to see why this is the more reasonable assumption. (One might have said the same thing about the exclusionary rule the day it went into effect.) Neither drug enforcement agents nor police officers generally suffer from a shortage of business. There are plenty of cases to investigate. If an officer lacks probable cause to make a search in a particular case and he is worried about the impact on him of an effective direct remedy, the more reasonable assumption, it seems to me, is that he will simply turn to another case where he thinks he does have probable cause or believes he can easily acquire it.

Professor Slobogin does not even consider the possibility that in some instances the police may not be able (or it may be too much of a hassle) to "get more cause." Id. at 444.

119. Kaplan, supra note 104, at 1037-38.

120. Waite (1955), supra note 1, at 192. 
Edward Barrett made a similar point at about the same time by asking: "Is not the court which excludes illegally obtained evidence in order to avoid condoning the acts of the officer by the same token condoning the illegal acts of the defendant?"121 I think not.

When courts admit unconstitutionally seized evidence, I do believe it is likely that significant numbers of police officers, as well as large segments of the public, will regard the official lawlessness as "not so bad," else the courts would not have permitted the evidence to be used. ${ }^{122}$ On the other hand, I find it hard to believe that the exclusion of evidence in a counterfeiting or burglary or narcotics case conveys a comparable message to the police and the public that these crimes are "not so bad." I can readily see how the admissibility of unconstitutionally acquired evidence may foster police misconduct, for the exclusionary rule is a "disincentive" - it removes a significant incentive for making illegal searches, at least when the police contemplate prosecution. But it is not easy to see how the exclusion of evidence in a particular counterfeiting or drug case could operate to promote future acts of counterfeiting or drug dealing.

So long as the exclusionary rule remains the only presently available, meaningful sanction or counterweight against unlawful searches and seizures (and even the rule's most robust critics concede that) - so long as "such limits as there are on [police powers to search and seize] are ... both defined and enforced almost exclusively in exclusionary rule litigation"123 - I think it fair to say that abolition of the rule and courts' use of illegally obtained evidence would likely be viewed as condoning the underlying police lawlessness.

Surely, however, violating the Fourth Amendment is not the only effective way nor the only feasible means presently available to bring a criminal to justice. Surely no one can deny that during the exclusionary rule era "apprehension and punishment [has been] pursued and inflicted with sufficient determination" that a would-be criminal has to "count them as substantial risks." 124 In the past twenty-five years the

121. Barrett, supra note 53, at 582; see also 8 JOHN HENRY WIGMORE, EVIDENCE $\S$ 2184, at 37 (3d ed. 1940).

122. A study of the attitudes of New York police toward the exclusionary rule, Loewenthal found that "regardless of the effectiveness of direct sanctions, police officers could neither understand nor respect a Court which purported to impose constitutional standards on the police without excluding evidence obtained in violation of those standards." Loewenthal, supra note 87, at 29-30. Most of the officers interviewed "interpret[ed] the Wolf case [overruled in Mapp] as not having imposed any legal obligation on the police since, under that decision, the evidence would still be admissible no matter how it was obtained." Id.

123. Silas Wasserstrom, The Incredible Shrinking Fourth Amendment, 21 AM. CRIM. L. REV. 257, 293-94 (1984).

124. Cf. Louis B. Schwartz, On Current Proposals to Legalize Wire Tapping, 103 U. PA. L. REV. 157, 158 (1954) ("A penal system gives us almost all we can get out of it if 
nation's prison population has quadrupled. ${ }^{125}$ The exclusionary rule has had its greatest impact on drug offenses but, partly as a result of tough mandatory sentences for these crimes, drug offenders have "swell[ed] the prison population to a size beyond the wildest dreams or nightmares of any mid-century law enforcement officers." 126

Since many lawful means are available to combat crime (including drug offenses) and to convict criminals (including drug dealers), how can it be seriously maintained that excluding the fruits of official illegality in a particular case condones the criminal activity involved in that case?

E. [The exclusionary rule] is a more or less frank choice of policy; a judicial reaction to utilitarian assumptions. ... There is no explicit statement lin the Fourth Amendment or its state constitutional counterparts] that evidence [obtained in violation of these constitutional provisions] may not be used in court. Whether some such preclusion is implicit depends upon judicial interpretation. And no student of decisions would declare the implication so obvious as to preclude a choice. ${ }^{127}$

Other critics of the exclusionary rule have hit this point even harder than did Professor Waite. Thus, Judge Malcolm Wilkey exclaimed: "[The exclusionary rule is] man-made, not God-given .... It's not even in the Constitution." complained that the Fourth Amendment "does not call for [and] does not even invite, the exclusion of evidence as a remedy for an unconstitutional search or seizure." 129 He went on to say that "the text obviously does not support the ... exclusionary rule" and the relevant history "emphatically rejects" it. ${ }^{130}$

apprehension and punishment are pursued and inflicted with sufficient determination that a would-be law violator must count them as substantial risks.").

125. ABRAMSKY, supra note 77 , at xii. In the 1980 s more than thirty states were under court order because of prison overcrowding. See Peter Applebome, Texas Prisons Stop Accepting Inmates Under Federal Order, N.Y. TIMES, Jan. 17, 1987, at 1. The Texas prison system "was forced to temporarily stop admitting new prisoners after its population crept above levels mandated by a federal court order." Id.

126. ABRAMSKY, supra note 77 , at 149 ; see also id. at 84 ("Nearly half of new admissions in New York in recent years have been for drug crimes.").

127. Waite (1933), supra note 1, at 760; see also Waite (1955), supra note 1, at 171.

128. Charles McC. Mathias Jr., The Exclusionary Rule Revisited, 28 LOY. L. REV. 1, 7 (1982) (quoting Hearings before the Attorney General's Task Force on Violent Crime (1998) (statement of Judge Malcolm Wilkey)). The author of this article was then-Senator Mathias, Chairman of the Senate Judiciary Subcommittee on Criminal Law. Shortly before this article was published, Mathias's subcommittee had held extensive hearings on various proposals to replace or to modify the exclusionary rule.

129. Amar, Against Exclusion, supra note 62, at 459.

130. Id. 
How can (should) a defender of the exclusionary rule respond to this criticism? One way is to turn to Professor Davies' study of the "original Fourth Amendment."

\section{ThOMAS Davies SHEDS Light ON WHY THE EXCLUSIONARY RULE IS "NOT EVEN IN THE CONSTITUTION." 131}

A plausible explanation for the failure of the Fourth Amendment to provide explicitly for an "exclusionary rule" is that the Framers did not focus on after the fact judicial control. (And, if they had, they probably would have assumed that not much illegally seized material would be offered in evidence.) The Framers concentrated on, and put their trust in, the warrant procedure. As Justice Jackson once observed, the Fourth Amendment "roughly indicate[s] the immunity of the citizen which must not be violated, goes on to recite how officers may be authorized, consistently with the right so declared, to make searches,",132 and then comes to an end, "apparently because [the Framers] believed that by thus controlling search warrants they had controlled searches." 133

Justice Jackson displayed a good grasp of the Framer's sense of the centrality of warrant authority, but furnished no supporting evidence for his conclusion. Fortunately, others, especially Thomas Davies, have - quite a bit.

As Davies spells out in his 1999 Michigan Law Review article, the Framers' statements about search and seizure "focused on condemning general warrants"; indeed, their "historical concerns were almost exclusively about the need to ban house searches under general warrants." "134 One reason the Framers thought that control of warrant authority, especially the prohibition against general warrant authority, "would suffice to preserve the right to be secure in person and house" was that they considered the ex officio authority of the framing-era officer to be meager. ${ }^{135}$ At common law, then, "controlling the warrant did control the officer for all practical purposes." 136

Another reason the Fourth Amendment does not specifically address warrantless searches and seizures is that the Framers

131. See supra text accompanying note 128 .

132. Harris v. United States, 331 U.S. 145, 195-96 (Jackson, J., dissenting).

133. Id. at 196 (Jackson, J., dissenting); see also Kamisar, Exclusionary Rule, supra note 91, at 571-79; Maclin, supra note 3, at 47 n.218; Silas J. Wasserstrom \& Louis Michael Seidman, The Fourth Amendment as Constitutional Theory, 77 GEO. L.J. 19, 83 (1988).

134. Davies, supra note 2, at 551.

135. Id. at 554.

136. Id. 
did not anticipate that a wrongful act by an officer might constitute a form of government illegality - rather, they viewed such misconduct as only a personal trespass by the person who held the office. Thus there was neither a need nor a basis for addressing the conduct of a warrantless officer in a constitutional provision regulating government authority. ${ }^{137}$

Although Telford Taylor and Davies differ over other aspects of the "original understanding" of the Fourth Amendment, they agree that the Framers did not fear, and did not have in mind, the eighteenth century peace officer. ${ }^{138}$ This is hardly surprising.

"[A]t the time of the drafting and ratifying of the Fourth Amendment, nothing even remotely resembling modern law enforcement existed." 139 As I have noted elsewhere:

Two hundred years ago the police had not yet assumed the functions of criminal investigation - indeed, no organized police forces had yet emerged. Until well into the nineteenth century, the only "police service" of any kind, even in our largest cities, was the "watch system" and "such protection as [it] afforded was provided only by night - generally between the hours of nine o'clock in the evening and sunrise" (and "sunrise" was variously interpreted as between three o'clock and five o'clock in the morning). ${ }^{140}$

As Davies observes, the peace officer of the framing-era, most commonly a constable who worked part-time and was not paid a salary, ${ }^{141}$ "often depended on the assistance of bystanders to execute an arrest." 142 If the officer attempted an arrest or search without a

137. Id.

138. As Professor Taylor observes, neither warrantless searches incident to arrest nor searches pursuant to specific warrants, such as the common-law warrant for stolen goods, concerned the colonists. See TAYLOR, supra note 113 , at $38-44$. The only victims of warrantless searches "were those who, as probable felons, were the objects of hue and cry, hot pursuit, or an arrest warrant." These searches posed "no threat to the honest householder, no fear of arrogant 'messengers' breaking open desks or trunks to search for smuggled jewels or libellous documents." Id. at 39. As for the common-law warrant for stolen goods, it "embodied the requisites of 'reasonable' search." Id. at 40.

139. Steiker, supra note 3, at 824. Professor Steiker adds, and I heartily agree with her:

The invention in the nineteenth century of armed, quasi-military, professional police forces, whose form, function and daily presence differ dramatically from that of the colonial constabulary, requires that modern-day judges and scholars rethink both the relationship between "reasonableness" and "warrants" and the nature of the Fourth Amendment remedies.

Id.

140. Kamisar, Exclusionary Rule, supra note 91, at 571-72 (quoting RAYMOND B. Fosdick, AMERICAN POLICE SySTEMS 61-62 (1920)). It was not until 1844 that the New York Legislature passed a law "creating 'a day and night police,' which forms the basis of modern police organization in America." FOSDICK, supra, at 66.

141. Davies, supra note 2 , at 620-21.

142. Id. at 621 . 
warrant then, as various common law sources described it, he acted " 'at his own risk' or 'at his peril.,"

In colonial days, "a search or arrest was presumed [to be] an unlawful trespass unless 'justified.' "144 And unlawful or unjustified arrests not only exposed the offending officer to suits for trespass damages (at a time when "[t]he common law recognized no broad doctrine of official immunity") ${ }^{145}$ but to "lawful resistance by bystanders or the target of his intrusion." 146

"The most salient feature of common-law authority for present purposes," emphasizes Davies, "is that a valid (specific) arrest or search warrant provided the officer with the clearest and strongest source of justification for an intrusion."147 "As long as [the constable] acted 'ministerially' - [i.e.,] within the [confines] of the warrant - it was an offense to resist him, or even refuse to assist him." ${ }^{148}$ Moreover, as long as he acted as the agent of the justice of the peace, the constable "was 'indemnified' against trespass liability." 149

The search and seizure cases of the 1760s that so greatly influenced the Framers - in London, the lawsuits by John Wilkes, John Entick and others against Lord Halifax and his messengers and in Boston, the protest against writs of assistance by James Otis - have a common characteristic. They involved, as Telford Taylor has noted, general warrants, statutory in origin, not warrants "subject to the restrictions and safeguards that the common law had thrown around the stolen goods warrant." 150 "It is both striking and enlightening," adds Taylor, "that independently, in London and Boston, the opponents of the [general] warrants based their attack primarily on unfavorable comparisons with the stolen goods warrants." ${ }^{151}$

\footnotetext{
143. Id. at 627 .

144. Id. at 624 .

145. Id. at 625 .

146. Id.

147. Id. at 626. Lawrence Lessig observes:
}

Essential to the Fourth Amendment [in the framing-era] was a structural incentive, one built in by the common law. As originally conceived, the police (or their equivalents) had a very strong personal incentive to secure a warrant before searches or seizures, for without a warrant, they were liable personally for their trespass.... [O]f course essential to this incentive was a common-law system of remedies that actually made it true that the police had an incentive - that is, a common-law system through which the wronged citizen could get damages for the wrongful search or seizure by the state official.

Lawrence Lessig, Fidelity in Translation, 71 TEXAS L. REV. 1165, 1229-30 (1993).

148. Davies, supra note 2 , at 626-27.

149. Id. at 627 .

150. TAYLOR, supra note 113 , at 40.

151. Id. For further discussion, see $i d$. at $34,37$. 
Were the Framers justified in putting their trust in the warrant procedure, i.e., the framing-era judges who were to issue warrants? Did the Framers have reason to think the courts might approve of general warrants on their own initiative? Akhil Amar believes so. He maintains that because they feared the "immunizing" effect of a warrant, the Framers viewed the "judges and warrants" as the "heavies." 152

Morgan Cloud has serious doubts about Professor Amar's claim that the Founders viewed judges as enemies of liberty and privacy in the context of searches and seizures. After noting that most colonial courts denied the general writ that customs officials sought in the 1760 s and 70 s and that, even when colonial judges were willing to grant more specific writs, customs officials believed they were attempting to obstruct enforcement of customs laws. ${ }^{153}$ Professor Cloud comments:

The history of these controversies permits, and perhaps even compels, the conclusion that in the years preceding the Revolution numerous colonial judges were important impediments to the use of writs of assistance to conduct general searches to enforce the customs laws. Had Professor Amar's examination of the Amendment's history considered this data, he might have reconsidered his views about judges. ${ }^{154}$

Davies' response to Amar's claim is more forceful:

152. Akhil Reed Amar, The Fourth Amendment, Boston, and the Writs of Assistance, 30 SUFFOLK U. L. REV. 53, 63, 67 (1996) (referring to "the guarantee of immunity provided by a warrant"). No one denies that warrants were one of a number of defenses available to searchers sued for trespass. However, Morgan Cloud points out:

[T] extrapolate from this narrow fact the broad principle that warrants served no protective function is simply to ignore the development of specific warrants. General warrants may have been akin to a license to search, but specific warrants came into prominence, particularly in the United States after 1782, precisely because they protected citizens' rights against such unreasonable methods.

Cloud, supra note 7, at 1730 (essay review of William J. Cuddihy, The Fourth Amendment: Origins and Original Meaning (1990) (unpublished Ph.D. dissertation, Claremont Graduate School)).

153. See Cloud, supra note 7, at 1738-39; Maclin, supra note 3, at 22-23; see also Kamisar, Exclusionary Rule, supra note 91, at 575 (quoting JACOB W. LANDYNSKI, SEARCH AND SEIZURE AND THE SUPREME COURT: A STUDY IN CONSTITUTIONAL. INTERPRETATION 36-37 (1966) and NELSON B. LASSON, THE HISTORY AND DEVELOPMENT OF THE FOURTH AMENDMENT TO THE UNITED STATES CONSTITUTION 6970, 72-73 (1937)):

Even after the Townshend Act of 1767 had disposed of all technical objections to the legality of the writs of assistance - even "in the face of mounting pressure from the executive which paid their salaries and could at any time remove them, or offer them preferment" the judges of most of the colonies had either refused or ignored applications for the writs. Surely an "independent judiciary" could be counted on to take seriously the command of the Fourth Amendment.

154. Cloud, supra note 7 , at 1739 . Professor Cloud relies primarily on William $\mathbf{J}$ Cuddihy's exhaustive 1696 page unpublished doctoral dissertation on the origins and original meaning of the Fourth Amendment, but he notes that other historians have documented the same behavior by colonial judges. Id. at 1739 n.111. 
[The claim] lacks historical support. The Framers did not express any general antagonism toward judges regarding search matters. In fact, Lord Camden, a judge, emerged as the hero of the Wilkesite cases, and the colonial judges who refused to issue general writs under the Townshend Act provided an example that may well have stimulated the developing American conception of judicial review.

[Moreover, Amar's claim about the "immunizing" effect of a warrant] is more in the nature of a hypothesis than a historical observation: it is not evident in historical statements .... [The sources Amar cites] expressed concern only that "general warrants" might be made legal - not concern regarding the "immunizing" effect of specific warrants. Amar has never identified a single historical complaint about the "immunizing" effect of a specific warrant. ${ }^{155}$

Although "the highly visible rulings in the Wilkesite cases had removed any possibility of upholding general warrants at common law," 156 those cases explicitly left open the possibility that general warrants might be made lawful by legislation. ${ }^{157}$ "Thus, the Framers' constitutional concern was preventing the legislature from authorizing use of general warrants." 158

\footnotetext{
155. Davies, supra note 2, at 586-88. Davies uses the

"Wilkesite cases" [also called the General Warrant Cases] as a collective label for the English trespass cases brought by [John] Wilkes and his supporters. The first set of cases were brought [in the early 1760s] by victims of a "nameless" general warrant (issued by the Secretary of State, Lord Halifax) that had directed the king's messengers to identify the persons responsible for publishing The North Briton No. $45 \ldots$ The messengers arrested [many people] ... searched [many] houses and seized private papers. The victims then brought trespass cases in the Court of Common Pleas presided over by Charles Pratt (later Lord Camden) ... [who instructed the] juries that the general warrant was illegal .... [T]he juries awarded trespass damages to the plaintiff victims....
}

A second set of cases... [grew out of a series] of arrests and searches involving publication of The Monitor. Those warrants identified the persons to be arrested, but were general as to the papers to be seized .... The main case was Entick v. Carrington (C.P. 1765), in which Lord Camden (Pratt) ruled that the papers search warrant was illegal ....

Parliament in 1766 passed resolutions condemning general warrants ... at least for certain purposes, unless Parliament itself authorized them. The final development came in the 1769 trial of Wilkes $v$. Halifax, in which John Wilkes won a judgment of 4000 pounds against [Lord] Halifax for having issued the "nameless" general warrant.

Id. at 563 n.21 (citation omitted).

156. Davies, supra note 2, at 657-58 (emphasis added). For a discussion of the Wilkesite cases, see supra note 155 .

157. Davies, supra note 2, at 658. In fact, as Davies points out, "after the Wilkesite cases .... Parliament reauthorized the general writs of assistance in the Townshend Act of 1767." Id.

158. Id. As Davies notes, "[w]hen describ[ing] the reason for declaration of rights, [the American Framers] typically stated that the declarations were meant to curb legislative power." Id. at 658 n.302. Consider, too, Justice O'Connor's dissent in Illinois v. Krull, 480 U.S. 340 (1987):

Statutes authorizing unreasonable searches were the core concern of the Framers of the Fourth Amendment. This Court has repeatedly noted that reaction against the ancient Act 
I think Silas Wasserstrom summed it up nicely two decades ago when he wrote, "[it] was not a lawless judiciary that the framers feared, but legislative tyranny and a treacherous executive. The framers believed that without a constitutional prohibition, the legislature would authorize issuance of general warrants by statute, just as Parliament had authorized the writs of assistance."159

An explicit constitutional prohibition would have (or should have) prevented Congress from authorizing general warrants. Moreover, even if Congress violated the explicit prohibition, general warrants had to be issued by judges and they could enforce the prohibition "simply by refusing to act." 160

So why was there any need for a remedy which has come to be known as the "exclusionary rule"?

James Madison, who undertook the task of drafting a proposal for federal rights amendments, did not want the rights amendments to appear in a supplemental bill of rights. He proposed instead that "most of the rights amendments" - including the provision that became the Fourth Amendment - "be added to Article I's limitations on Congressional power." 161 This is a strong indication that "Madison conceived his proposal as a deprivation of Congress's power to authorize use of general warrants - not as a constraint on the conduct of ordinary officers." 162

of Parliament authorizing indiscriminate general searches by writs of assistance ... was the moving force behind the Fourth Amendment.

480 U.S. 340, 362 (1987) (O'Connor, J., joined by Brennan, Marshall, \& Stevens, JJ., dissenting) (rejecting the holding that the exclusionary rule does not apply when police act in objectively reasonable reliance on a statute which authorizing what turns out to be an unlawful search).

159. Wasserstrom, supra note 123 , at 287 . "[T] or] General Warrant Cases were not judicial warrants at all, but were issued by Lord Halifax, an executive official." Id. at 286.

160. Davies, supra note 2, at 701, 702. After all, a court's refusal to act was "the remedy Otis had sought in 1761 and that the colonial courts had provided when they refused to issue 'illegal' general writs under the Townshend Act." Id.

161. Id. at 700. The placement of the search and seizure provision in a separate "bill of rights" did not occur until the eleventh hour. After the "Committee of Eleven" of the House of Representatives had endorsed Madison's proposal to insert the rights amendments with the text of the Constitution and after the full House had debated the search and seizure provision (but before the conclusion of the debate on all the rights amendments), Roger Sherman's motion to put the amendments in a supplementary document passed. $I d$. at 715 n.475.

According to Professor Davies, Sherman's motion did not seem to reflect any disagreement that the amendments should be aimed at Congress. Rather, he "seems to have sought the supplementary format in the hope of downgrading the importance of the amendments, and possibly of warding off additional amendments to the Constitution." Id. at 716 n.475

162. Id. at 700-01. Madison's single-clause version of what became the Fourth Amendment did not address warrantless intrusions. Rather his proposal defined what he called "[t]he rights of the people to be secured in their persons, their houses, their papers, and their other property from all unreasonable searches and seizures" solely in terms of 
This helps explain why Madison's provision contained no statement of a remedy for a violation of the search and seizure right. First of all, an explicit limitation on congressional power would prevent Congress from authorizing general warrants. In any event, the Framers "would have expected, at a minimum, that courts would decline to enforce legislation that conflicted with the essential rights announced in the Constitution." 163

There is still another reason the Fourth Amendment does not contain an exclusionary principle or any other "remedy" for peace officers' violations of the search and seizure provision. The Framers "did not equate an officer's misconduct with government illegality; rather they perceived only personal misconduct when an officer exceeded his official authority." 164 Therefore, "they had neither a motive nor a basis for addressing the conduct of ordinary officers in constitutional provisions." 165

If the Fourth Amendment's controls on the issuance of warrants were "the answer of the Revolutionary statesmen to the evils of searches without warrants and searches with warrants unrestricted in scope," 166 they are not a sufficient answer today. Nor have they been for quite some time. The reason is that in the nineteenth century, various developments "destroyed the common-law premises" that had led the Framers to believe "that a ban against general warrants would suffice to ensure the right to be secure in person and house": ${ }^{167}$

New concerns about crime and social disorder during the nineteenth century gave rise to a perception that the common-law structure of law enforcement was inadequate to meet the needs of an increasingly complex and urban society. Contemporaneously with the advent of

\footnotetext{
"warrants issued without probable cause... or not particularly describing the places to be searched, or the person or things to be seized." Id. at 697 (quoting James Madison, Speech to the House of Representatives (June 8, 1789) in 12 THE PAPERS OF JAMES MADISON 197 (Robert A. Rutland et al. eds., 1977).
}

163. Davies, supra note 2 , at 701.

164. Id. at 660 . "The exclusionary rule," adds Davies, "is premised on the notion that an unconstitutional government act is void - but exclusion has never been seriously proposed as a consequence of private wrongdoing." Id. at 663 .

165. Id. at 663 .

166. United States v. Rabinowitz, 339 U.S. 56, 70 (1950) (Frankfurter, J., dissenting). Justice Frankfurter's position in this case was adopted when Rabinowitz was overruled in Chimel v. California, 395 U.S. 752 (1969).

167. Davies, supra note 2 , at 725. 
police departments and career officers, courts and legislatures drastically expanded the ex officio authority of the warrantless officer. ${ }^{168}$

These developments pushed warrant authority toward the margins of law enforcement procedure and thus destroyed the common-law premises that had grounded the Framers' belief that a ban against general warrants would suffice to ensure the right to be secure in person and house. Likewise, these developments undermined trespass actions against individual officers as a means of enforcing legal limits on search and arrest authority. By the end of the nineteenth century, the warrantless officer posed a far more potent threat to the security of person and house than the Framers had ever anticipated. ${ }^{169}$

The Framers of the Fourth Amendment could hardly have been expected to foresee a time when the great bulk of searches and seizures would be made without any warrants ${ }^{170}$ - a time when a single police force would make tens of thousands of warrantless searches every year. ${ }^{171}$ Worse still, "the state tort actions that provided the traditional remedy for false arrest and trespass had become ineffective against modern police departments." ${ }^{172}$ The Framers had concentrated their fire on general warrants because in their immediate past unacceptable executive discretion had taken this particular form, but the social and legal environment had changed so dramatically that controlling warrants could no longer control searches and seizures.

Applying the "original meaning of the language of the Fourth Amendment" in a very different world "would subvert the purpose the Framers had in mind when they adopted the text." ${ }^{173}$ Davies continues:

The text of the Fourth Amendment clearly anticipated that there would be a "right to be secure" in one's person, house, papers, and effects. If there is any term in the text that might be described as the core or essence of the provision, "right to be secure" is the leading candidate. Thus, one should not advocate a modern meaning for the Fourth

168. Id. As Davies observes elsewhere in his article, during the nineteenth century the justification for warrantless arrests by officers were relaxed. The officer no longer had to prove that the felony for which he had made an arrest had actually been committed. The officer was also allowed to rely on unsworn information provided to him by others even when no one else made a felony charge. These developments sapped the validity of the trespass remedy as a means of regulating warrantless arrests. Moreover, since an innocent person could not easily tell whether the arresting officer had "probable cause," the right to resist unlawful arrest "became unworkable and gradually collapsed." The emergence of professional police, and eventually armed police, also made resistance to unlawful arrests imprudent. Id. at 634-39.

169. Id. at 725 .

170. See supra text accompanying notes 111-114.

171. See supra note 113 .

172. Dripps, supra note 44 , at 1600.

173. Davies, supra note 2 , at $740-41$. 
Amendment that would render the right to be secure a practical nullity. ${ }^{174}$

At the opportune time, probably as the result of the development of "state action" doctrine under the Fourteenth Amendment, police misconduct came to be viewed as government illegality. ${ }^{175}$ Finally, more than a century after the framing, both a need and a doctrinal basis existed for applying the command of the Fourth Amendment to the conduct of a warrantless officer. ${ }^{176}$

In the landmark Weeks case, ${ }^{177}$ the Court saw the need to adapt the Fourth Amendment to the dramatically changed socio-legal context and utilized the new doctrinal basis for doing so. ${ }^{178}$ The Weeks Court, per Justice Day, stated that the protection of the Fourth Amendment "is equally extended to the action of the Government and officers of the law acting under it."179 Moreover, the Court characterized the unlawful search by the federal marshal as misconduct "under color of his office in direct violation of the constitutional rights of the defendant."180 "Put simply, Weeks initiated the development of modern doctrine by reading the Fourth Amendment as a broad protection of a right to be secure in one's house and papers rather than as a simple ban against general warrants."181

"[C]hanging the law," or, one might say, changing social and legal institutions, a noted legal philosopher observed, "is like making a change in the intricate plot of a highly organized drama. You cannot change one part without other parts being affected in unexpected ways." 182

A good illustration is Tennessee $v$. Garner, ${ }^{183}$ which held that, unless the police have probable cause to believe that the suspect poses a danger to the police or to the community at large, a police killing of

174. Id. at 741.

175. See id. at 554,667 . As we have seen, the Framers viewed warrantless intrusions by a peace officer as only a personal trespass by the officer.

176. See id. at 667, 729-30.

177. Weeks v. United States, 232 U.S. 383 (1914).

178. As Davies points out, Weeks was decided only a year after the Court held, in Home Tel. \& Tel. Co. v. City of Los Angeles, 227 U.S. 278, 287 (1913), that conduct by a state regulator alleged to violate state law was misconduct "under color of" state law and therefore constituted state action. Davis, supra note 2, at 730 n.519.

179. Weeks, 232 U.S. at 394 (emphasis added).

180. Id. at 398 (emphasis added).

181. Davies, supra note 2, at 730-31; see also Maclin, supra note 3, at 49-51.

182. Morris R. COHEN, ReASON AND NATURE 421 (2d ed. 1953).

183. 471 U.S. 1 (1985). 
a fleeing felon is an "unreasonable seizure" within the meaning of the Fourth Amendment. The state insisted that because the prevailing view in the framing era (and for a considerable time thereafter) was that, in order to effectuate an arrest, a peace officer could kill any fleeing felon, whatever the circumstances, that rule must be upheld 200 years later. ${ }^{184}$ A 6-3 majority, per White, J., disagreed:

Because of sweeping change in the legal and technological context [since the eighteenth century], reliance on the common-law rule in this case would be a mistaken literalism that ignores the purposes of a historical inquiry. ${ }^{185}$

$$
* * *
$$

[T]hough the common-law pedigree of Tennessee's rule is pure on its face, changes in the legal and technological context [these past 200 years] mean the rule is distorted almost beyond recognition when literally applied. ${ }^{186}$

Justice White explained that the common-law rule arose at a time when virtually all felonies were punishable by death (and thus the killing of a resisting or fleeing felon resulted in no greater "punishment" than that authorized for the crime of which he was suspected), and at a time when all felons were considered quite dangerous. But these justifications for the old rule do not "make[] sense today." ${ }^{187}$ For almost all crimes once "punishable by death no longer are or can be."188 Moreover, many crimes that were misdemeanors at common law or nonexistent at that time are now classified as felonies. Indeed, nowadays "numerous misdemeanors involve conduct more dangerous than many felonies." 189

Still another historical point had to be made: the common law had formed long before handguns were carried by the police. ${ }^{190}$ Thus the old rule had developed at a time when the police could use deadly force "almost solely in a hand-to-hand struggle during which, necessarily, the safety of the arresting officer was at risk." ${ }^{191}$ Not until more than a half-century after the adoption of the Fourth Amendment "did it become possible [for the police] to use deadly force from a

184. See id. at 12-13.

185. Id. at 13 .

186. Id. at 15 .

187. Id. at 14 .

188. Id.

189. Id.

190. Police officers did not carry handguns, pointed out the Court, until the second half of the nineteenth century. $I d$. at 15 .

191. Id. at 14-15. 
distance as a means of apprehension." ${ }^{92}$ Thus, an officer's "use of deadly force under the standard articulation of the common-law rule has an altogether different meaning - and harsher consequences now than in past centuries." 193

What Professor Davies has done is essentially what the Garner Court did when it showed why the common-law rule regarding fleeing felons no longer made much sense. In the exclusionary rule context too, the "sweeping changes" that have occurred in the past 200 years - the decline and fall of the tort remedy against transgressing officers, the development of armed, professional police with powers far greater than those of the eighteenth century peace officer to make warrantless arrests and searches and to overcome resisting suspects, and the vast increase in the number of warrantless arrests and searches that take place every day - mean that literally applying the Fourth Amendment, with its framing era premises and assumptions, would greatly distort - indeed, subvert - " $[\mathrm{t}]$ he right of the people to be secure in their persons, houses, papers and effects."194

"[T]he temper of the ... arguments in the Federalist papers and other contemporaneous discussion, the action of the early Congresses and the language of the early opinions," Telford Taylor once observed, "are all to me instinct with the notion of a charter intended to preserve certain values through, and in spite of, changing circumstances in the future." 195 If so (and I cannot believe that many students of constitutional law would disagree with Professor Taylor), what the Court did in the Weeks case is quite appropriate. Just as, as almost everyone recognizes, "changes in technological circumstances inform constitutional interpretation, as with electronic surveillance, so changes in the legal environment need to be taken into account."196 After all, "if we do not want a rubber Constitution, neither do we want a rusty one."197

\section{SOME FINAL THOUGHTS}

"If history could be told in all its complexity and detail," an astute historian once observed, "it would provide us with something as

192. Id. at 15 .

193. Id.

194. U.S. CONST. amend. IV; see also Alschuler, supra note 116, at 206. See generally Kramer, supra note 7, at 1639, 1641.

195. TAYLOR, supra note 113 , at 12-13.

196. Dripps, supra note 44 , at 1600.

197. TAYLOR, supra note 113 , at 14. 
chaotic and baffling as life itself." ${ }^{198}$ However, this historian goes on to say, because history can be condensed, "there is nothing that cannot be made to seem simple, and the chaos acquires form by virtue of what we choose to omit."199

Therefore, although I concur in George Thomas's view that Thomas Davies' proof of the "original understanding" of the Fourth Amendment "is a little less than incontestable, but for me ... utterly convincing," 200 I am well aware that an opponent of the exclusionary rule may say of him what a supporter of the rule may say of someone like Akhil Amar:

[W]e must beware even of saying, 'History says...' or 'History proves...' as though she herself were the oracle .... Rather we must say to ourselves: 'She will lie to us till the very end of the last crossexamination.' 201

Indeed, someone unhappy with the conclusions that Davies (or Amar) has reached might put it still more forcefully: It is a remarkable if familiar fact that law professors, like Supreme Court Justices, almost always find that the Framers' views mirror their own. ${ }^{202}$

Relying in part on an article by Carol Steiker (who states that "almost no one" really believes that "we should be bound for all time by the specific intentions or expectations of the Framers" about, inter alia, "what sorts of remedies are required for violations of the Fourth Amendment"), ${ }^{203}$ Wayne LaFave concludes that, although "surely relevant," reliance on the "intent of the Framers" and the history of the Fourth Amendment "is of limited utility" in determining the scope and content of the Amendment. ${ }^{204}$

Professor Davies, no less than Professors LaFave and Steiker, is uneasy about reading the provisions of the Bill of Rights as statements of broad principles:

198. Herbert Butterfield, The Whig InTERPRETation of History 97 (W.W. Norton 1965) (1931). I am indebted to Morgan Cloud for calling this book to my attention.

199. Id.

200. George C. Thomas III, When Constitutional Worlds Collide: Resurrecting the Framers' Bill of Rights and Criminal Procedure, $100 \mathrm{MICH}$. L. REV. 145, $155 \mathrm{n} .32$ (2001).

201. BUTTERFIELD, supra note 198, at 131-32.

202. This is a slightly revised version of David Sklansky's comment about "the remarkable if familiar fact that Supreme Court Justices, like law professors, almost always find that the Framers' views mirror their own." David A. Sklansky, The Fourth Amendment and Common Law, 100 COLUM. L. REV. 1739, 1770 (2000).

203. Professor LaFave quotes a long passage from Steiker, supra note 3, at 823-24. A portion of this passage is quoted in note 213 infra.

204. See LAFAVE, supra note $16, \S 1.1$ (a), at 6 . Of course, if I were Professor LaFave, and had written three editions of what is now a five-volume treatise on the contemporary meaning of the Fourth Amendment, to say nothing about many annual pocket parts, I would not be too excited either about writing one or two volumes on the history of the Fourth Amendment. 
The historical record of the framing indicates that the Framers saw the Fourth Amendment as a specific constitutional barricade against the unique threat which legislative approval of general warrants posed for the structure of common-law authority - not as a general statement of an abstract principle....

The fact that we now face issues the Framers never anticipated may leave us little choice but to treat the constitutional texts as expressions of broad principles, rather than as specific solutions to specific historical threats. Indeed, the expansive treatment now accorded the Bill of Rights can be justified as a replacement for the Framers' unfulfilled expectation of a permanent structure of common law rights. However, we should not confuse our predicament with the historical character of the texts. At least as far as the procedural protections of the Bill of Rights are concerned, the retreat to principles is only a modern response to changed circumstances; it is not the Framers' understanding of the text. ${ }^{205}$

Davies - again, no less than LaFave and Steiker - is also aware of the difficulties involved in forming a clear picture of the Framers' "intentions" or "expectations" about the constitutional provisions, ${ }^{206}$ but he maintains that the Framers intentions and expectations regarding the Fourth Amendment (or at least certain aspects) constitute an exception:

One objection that is sometimes raised regarding attribution of the original meaning or purpose of a constitutional text is that such statements ignore the likely variation of attitudes and understandings that may have existed among the various groups of persons (drafters, federal legislators, state legislators, commentators) who might be lumped together under the label of "Framers." I have no doubt that is a genuine difficulty for assessing the historical meaning of certain aspects of the Constitution or especially of the Fourteenth Amendment. It is possible to speak of "the" original meaning of the Fourth Amendment, however, because there simply is no indication in the historical sources of any controversy or disagreement as to its meaning (with the exception of the mysterious choice of "effects") among any of the persons who could be considered "Framers."207

Although his prodigious research, thoughtful analysis, and careful writing suggest otherwise, Professor Davies may have overstated his case. Unless and until someone else comes along and shows the flaws in his study, however, Davies' historical research cannot be ignored in the never-ending debate over the exclusionary rule.

I hasten to add that I would be willing, indeed happy, to engage in a debate over the exclusionary rule without regard to colonial history and the "intent" or "expectations" of the Framers. But as long as

205. Davies, supra note 2, at 745.

206. See Steiker, supra note 3 , at 823.

207. Davies, supra note 2, at 723-24 n.505. 
opponents of the exclusionary rule maintain that the Fourth Amendment "does not require," "call for" or "even invite" the exclusionary rule ${ }^{208}$ and as long as some Supreme Court justices believe that the Court is "most vulnerable and comes nearest to illegitimacy when it deals with judge-made constitutional law having little or no cognizable roots in the language or design of the Constitution ${ }^{\$ 209}$ it will be hard to keep the colonial history and the "intent" of the Framers out of the debate. It will be hard, as Professor Steiker puts it, for supporters of the exclusionary rule to resist "fight[ing] fire with fire.".210

Moreover, and more generally, it is all very well to talk about the need to "formulate notions of the Framers' intent at some higher level of abstraction" 211 and, as times change, "to accommodate constitutional purposes more general than the Framers' specific intentions," ${ }^{212}$ but how does one go about doing this without first determining the Framers' specific intentions? And how does one go about identifying the significant ways in which conditions have changed since colonial times without first establishing what colonial times were like?

Davies does discuss, at considerable length, why the Framers omitted from the text of the Fourth Amendment any mention of a remedy for violating it. More generally, he discusses why the Framers probably never thought at all about an exclusionary rule or, if they did, why they did not believe one was necessary. But colonial history is not the only history he talks about. Davies also spends much time and effort explaining why and how, in the many years since the adoption of the Fourth Amendment, changing times and changing circumstances seriously undermined the presuppositions and expectations regarding the drafting and adoption of the search and seizure provision.

It strikes me that this is essentially what Professor Steiker did, albeit in much more summary fashion (and she did it quite well), when she responded to what might be called Professor Amar's "intentionalist/originalist" attack on the search and seizure exclusionary rule. ${ }^{213}$

208. Amar, Against Exclusion, supra note 62, at 459; see also Amar, First Principles, supra note 3, at 785 (claiming that the Supreme Court "has concocted the awkward and embarrassing" search and seizure exclusionary rule). Consider, too, Professor Amar's contention that colonial history "emphatically rejects any idea of exclusion." Amar, Against Exclusion, supra note 62, at 459.

209. Bowers v. Hardwick, 478 U.S. 186, 194 (1986).

210. Steiker, supra note 3 , at 822 ("A common reaction to invocations of intentionalist authority is to fight fire with fire.").

211. Id. at 824 .

212. Id.

213. Observed Professor Steiker: 
Telford Taylor once asked: "Does the Constitution mean what it was meant to mean, or what it has come to mean, or what it ought to mean?"214 If I understand him correctly, he gave the most weight to what the Constitution has come to mean. ${ }^{215}$

If so, the search and seizure exclusionary rule should fare well. The federal exclusionary rule was established in 1914, the "stone age" for American constitutional-criminal procedure. The exclusionary rule was imposed on the states many years later, ${ }^{216}$ but still some time before Gideon ${ }^{217}$ and Miranda ${ }^{218}$ What the Court said of Miranda two years ago may surely be said of the exclusionary rule as well: it has become "part of our national culture." 19

[Professor Amar's focus on colonial history, inter alia, to attack the exclusionary rule] ignores at least two crucial changes between colonial times and the present that must inform our current readings of the Fourth Amendment as a whole. First, at the time of the drafting and ratifying of the Fourth Amendment, nothing even remotely resembling modern law enforcement existed. The invention in the nineteenth century of armed, quasi-military, professional police forces, whose form, function, and daily presence differ dramatically from that of the colonial constabulary, requires that modern-day judges and scholars rethink ... the nature of Fourth Amendment remedies. Second, the intensification of inter-racial conflict in our society during the Civil War and Reconstruction, and the myriad ways in which this conflict has intersected with law enforcement, likewise necessitate new constructions of the Fourth Amendment. It is no accident that the modern pillars of Fourth Amendment law attacked by Professor Amar were significantly fortified during the $1960 \mathrm{~s}$ at the same time that the Supreme Court and the rest of the country began to address systematically our legacy of racial discrimination.

Id.

214. TAYLOR, supra note 113 , at 5 .

215. See id. at 7, 14-15.

216. Mapp v. Ohio, 367 U.S. 643 (1961).

217. Gideon v. Wainwright, 372 U.S. 335 (1963).

218. Miranda v. Arizona, 384 U.S. 436 (1966).

219. Dickerson v. United States, 530 U.S. 428,443 (2000). In fact, some twenty years ago, shortly after he had stepped down from the Supreme Court, Justice Potter Stewart did state that "the exclusionary rule is now part of our legal culture." Potter Stewart, The Road to Mapp v. Ohio and Beyond: The Origins, Development and Future of the Exclusionary Rule in Search-and-Seizure Cases, 83 CoLUM. L. REV. 1365, 1386 (1983).

Consider, too, Taylor, writing in 1969:

Apart from expressing a belief that [Mapp] is here to stay, I will only venture a reminder that the Court's division in the case, sharp as it was, did not concern the merits of the exclusionary rule. The disagreement concerned only the federal dimension of the constitutional question: should the states by left free to apply or not to apply the exclusionary rule according to state law? ... [T]here is not a word in the dissenting opinions suggesting that the rule is intrinsically bad. Especially in view of the pre-Mapp trend in the state courts, I should think it likely that the case will weather even substantial changes in the Court's membership.

TAYLOR, supra note 113, at 20-21. 